"This is the peer reviewed version of the following article: [Hauptfleisch M, Putnins TJ, Lucey B. Who sets the price of gold: London or new York? Journal of Futures Markets 36(6):564-586 01 Jun 2016], which has been published in final form at [ http://dx.doi.org/10.1002/fut.21775 ]. This article may be used for non-commercial purposes in accordance with Wiley Terms and Conditions for Self-Archiving." 


\title{
Who sets the price of gold? London or New York
}

\author{
Martin Hauptfleisch*, Tālis J. Putniņš, and Brian Lucey
}

November 30, 2015

Forthcoming, Journal of Futures Markets

\begin{abstract}
We investigate which of the two main centers of gold trading-the London spot market and the New York futures market - plays a more important role in setting the price of gold. Using intraday data during a 17-year period we find that although both markets contribute to price discovery, the New York futures play a larger role on average. This is striking given the volume of gold traded in New York is less than a tenth of the London spot volume, and illustrates the importance of market structure on the process of price discovery. We find considerable variation in price discovery shares both intraday and across years. The variation is related to the structure and liquidity of the markets, daylight hours, and macroeconomic announcements that affect the price of gold. We find that a major upgrade in the New York trading platform reduces the relative amount of noise in New York futures prices, reduces the impact of daylight hours on the location of price discovery, but does not greatly increase the speed with which information is reflected in prices.
\end{abstract}

\footnotetext{
Martin Hauptfleisch is at Finance Discipline Group, University of Technology Sydney, Sydney, Australia and Capital Markets Cooperative Research Centre, Sydney, Australia. Tālis J. Putniņš is at Finance Discipline Group, University of Technology Sydney, Sydney, Australia and Department of Economics, Stockholm School of Economics in Riga, Riga, Latvia. Brian Lucey is at Trinity Business School and Institute for International Integration Studies, Trinity College Dublin, Dublin, Ireland. We thank the Securities Industry Research Centre of Asia-Pacific and Thomson Reuters for providing access to data used in this study. We also thank Dirk Baur, Arman Eshragi, Sean Foley, Lars Nordén, David Michayluk, and participants at the Auckland Centre for Financial Research Conference on Derivatives Markets, the KLU Finance Meeting on Gold, Capital Markets Co-operative Research Centre, and University of Technology Sydney for helpful comments and suggestions.
}

JEL Classification: G13, G14, G15

Keywords: Price Discovery; Gold; Gold Futures; Market Microstructure

* Corresponding Author, Finance Discipline Group, University of Technology Sydney, 15 Broadway, Ultimo, Sydney, Australia. Tel: +61 29514 3088. E-mail: Martin.Hauptfleisch@uts.edu.au 


\section{Introduction}

Gold is one of the most traded assets worldwide. In 2011, the estimated daily turnover in the international gold market was 4,000 metric tons, equivalent to over $\$ 240$ billion. This is approximately the same as the daily dollar volume of trade on all of the world's stock exchanges combined. ${ }^{1}$ The turnover in the gold market exceeds turnover in all but four currency pairs. ${ }^{2}$ The two major centers for gold trading, the London over-the-counter (LOTC) spot market and the New York Mercantile Exchange Futures Market (COMEX), account for approximately 78.0\% and $7.7 \%$ of the total gold turnover, respectively. Although gold futures account for a smaller proportion of total turnover, several studies of other markets show that futures play an important role in price discovery (Bohl et al., 2011; Boyd \& Locke, 2014; Dolatabadi et al., 2015; Rosenberg \& Traub, 2009), although not in all settings (e.g., Cabrera et al., 2009). Despite the enormous size of the international gold market, somewhat surprisingly, relatively little is known about how information is incorporated into gold prices. This paper aims to fill this void.

Gold trade internationally is largely decentralized, with physical gold traded in OTC markets and financial securities linked to gold (including futures, options and other derivatives) traded on organized exchanges and trading platforms worldwide. ${ }^{3}$ Understanding the price formation process and where/how information about the value of gold is impounded into its price is paramount to investors and regulators due to the economic significance of gold. The introduction of new capital requirements for banks have brought attention to the pivotal role that liquid assets play in bank risk management, and in particular to the role that gold can play in diversifying a firm's liquid assets.

In this paper we answer two main questions: where do innovations in the price of gold originate, and how has this changed over time? The demand for gold arises from a variety of sectors. Gold retains a significant industrial and dental use pattern, is popular as an adornment, is held as a quasi-reserve currency by official sectors, and is a popular investment vehicle. Supply also is disaggregated, with new gold coming from mines, recycled gold coming from scrap and

\footnotetext{
1 According to the World Federation of Exchanges 2011 Annual Report (available at http://www.worldexchanges.org/files/statistics/pdf/2011_WFE_AR.pdf), the total value of all equities traded in electronic order books (stock exchanges) around the world in 2011 is $\$ 63$ trillion, which, assuming 220 trading days per year, is a daily turnover of around $\$ 287$ billion.

${ }^{2}$ The four currency pairs include USD/EUR, USD/YEN, USD/GBP, and USD/AUD with turnover figures of $\$ 1,101$ billion, $\$ 568$ billion, $\$ 360$ billion, and $\$ 249$ billion respectively (Report on global foreign exchange market activity in 2010).

${ }^{3}$ The emergence of the gold market is described in O'Callaghan (1991).
} 
reuse, and releases of investment and official sector holdings. As a consequence of this, the influences on the gold price are many, as are the sources of market moving information. Given the geographic dispersion in new information about the value of gold, no trading venue will have a clear locational advantage, which is an important consideration in equity price discovery (Anand et al., 2011). Furthermore, the large distances between the different trading locations for gold give rise to relatively high latency in information transmission and limit high-frequency trading (Frino et al., 2014).

We use intraday data on gold prices in the LOTC and the US futures market during the period 1997-2014. This allows us to examine variation in price discovery through the course of several years, examine the effects of market structure changes during our sample, and analyze the intraday patterns in price discovery and the process by which specific news announcements are impounded into prices.

A striking result of our analysis is that although the volume of gold traded in the LOTC spot market is approximately ten times higher than that of the US futures market $(78.0 \%$ market share compared to $7.7 \%$ ), the futures market tends to lead in incorporating new information about the value of gold. This result highlights the importance of market structure and instrument type. Our results support the notion that the centralization and relative transparency of the futures market contribute to its disproportionately large role in price discovery. It is also likely that the low transaction costs, inbuilt leverage and ability to avoid dealing with the underlying asset, make futures contracts an attractive option for those that trade gold as a financial asset, and such trades contribute disproportionately to price discovery.

Our second key finding reinforces the importance of market structure on the process of price discovery. During our sample period, at the end of 2006, the US futures market changed from an open outcry floor-based system to the fully electronic, nearly 24-hour low latency GLOBEX platform. We find that this change notably decreased the amount of noise in US futures prices relative to the UK spot prices, but did not have a large impact on the speed with which the futures market reflects new information about the price of gold.

Our third key finding is that although the US futures market leads with respect to price discovery overall, several factors affect the extent to which it leads. Our results indicate that price discovery shares vary substantially at both the daily and intraday levels, with the two markets changing their relative importance throughout the day and from day to day. Prior to the 
US futures market's introduction of the fully electronic GLOBEX platform, the price discovery shares of the two major trading centers are largely dictated by daylight hours within each market locale - the LOTC market plays a more important role during UK daylight hours and the US futures market plays a more important role during US daylight hours. With the upgrade of the futures market to the GLOBEX platform and introduction of incentives for international participants, intraday variation in price discovery declines and the futures market takes a consistent lead throughout the day irrespective of market hours. This finding illustrates how highly accessible electronic platforms can decrease the importance of geographic location and create a more integrated global market. ${ }^{4}$

We hypothesize that some of the variation in daily and intraday price discovery shares is related to specific news events that affect the value of gold. The importance of gold to central banks and governments suggests that macroeconomic announcements and central bank announcements may affect the price of gold and the location of price discovery (Batten et al., 2010; Hautsch et al., 2011; Elder et al., 2012). The information contained in specific announcements may have a tendency to be incorporated into specific markets, generating variation in price discovery shares. Furthermore, there is evidence that there may be information leakage from the UK gold price fix, in that the market reacts to the fix while the fix is being undertaken (see Caminschi \& Heaney, 2014). However, to what extent the market reaction represents the particular structure of the fix at the time and to what extent it reflects actual price sensitive information leakage is less clear. Leakage from the fix could influence the location of price discovery. To examine these possibilities, we regress price discovery shares on dummy variables for gold fixing times and various major macroeconomic announcements. The LOTC market is relatively faster at reflecting new information around the AM gold price fixing. Also, our results indicate that US GDP announcements are associated with an increase in the US futures market's share of price discovery, whereas US employment announcements including Non-Farm Payroll are associated with an increase in noise in futures prices. UK announcements in general have no effect on the location of price discovery, although some are associated with an increase in noise in the LOTC.

Our findings contribute to the literature on how different market structures and securities affect the nature of price discovery. It is generally accepted that futures contracts lead their

\footnotetext{
${ }^{4}$ The efficacy of floor and electronic trading is investigated by Ates and Wang (2005)
} 
respective underlying assets in price discovery (Bohl et al., 2011; Rosenberg \& Traub, 2009), yet this relationship has not been confirmed in the gold market despite its immense size and economic impact. Cabrera et al. (2009) find that foreign exchange spot quotes consistently lead foreign exchange futures prices. The gold and foreign exchange markets are similar in that the spot market accounts for a substantial share of trading activity, and therefore the findings of Cabrera et al. (2009) suggest that ex-ante it is not obvious that gold futures would lead the spot market in price discovery.

Our findings are also related to other studies of gold price discovery, including comparisons between COMEX Futures and Tokyo Commodities Exchange Futures (Xu \& Fung, 2005; Lin et al., 2008) and Indian gold futures (Fuangkasem et al., 2014). These studies conclude that COMEX dominates price discovery, which in addition to its considerable volume, is why we choose to compare gold prices from COMEX with those in the UK spot market. The papers above do not examine the LOTC spot market, which accounts for $78.0 \%$ of global trade. Lucey et al. (2013) compare the LOTC market and COMEX using daily data and find that price leadership shifts between the two markets. Our use of intraday data allows for more accurate measurement of price discovery and allows us to characterize intraday variation in the location of price discovery, which is important in this 24-hour global market. ${ }^{5}$ Furthermore, our detailed analysis of the determinants of gold price discovery is novel in this literature. A final and nontrivial contribution of our paper to the literature on gold price discovery is in disaggregating gold price discovery into two distinct components - the relative speed at which information is reflected in prices and the relative noise in prices. The disaggregation is important as we show that several of the factors that influence price discovery have opposite effects on the two components of price discovery. Without the disaggregation, the effects of several of the factors would be obfuscated.

Our study also contributes to the broader literature on gold. Prior research in this area is concerned with the hedging value of gold and whether it can be considered a safe haven (Baur $\&$ Lucey, 2010; Baur \& McDermott, 2010; Capie et al., 2005), the relationship between gold and other precious metals (Batten et al., 2010), psychological price barriers in gold (Aggarwal \& Lucey, 2007) and its investment value (Hillier et al., 2006; Sherman, 1982).

\footnotetext{
${ }^{5}$ With daily observations, the lead-lag relations between markets that exist at intra-day horizons appear as contemporaneous correlation.
} 
Our comparison of physical gold and its derivative securities contributes to the study of physical and financial assets. Physical gold and futures contracts on gold are by nature very different, even though both share the same underlying asset. The former is used by banks, jewelers and manufacturers of many kinds, whereas the latter is primarily used by hedgers and speculators. Our comparison provides an insight into the price setting power of each group, with the pricing lead of the futures market indicating that hedgers and speculators are more sensitive to new information. Such a conclusion is intuitive as this group's main focus is the price of gold, as opposed to the use of gold. Our result is consistent with the current declining physical and increasing financial demand for gold.

This paper proceeds as follows. Section 2 discusses the structures of the LOTC and COMEX. Sections 3, 4 and 5 describe the data, method, and results, respectively, and Section 6 concludes.

\section{Market structure}

COMEX and the LOTC markets are structurally different. COMEX is a centralized exchange in which all orders are routed through one system. The LOTC market on the other hand is a decentralized over-the-counter market in which a number of dealers each quote bid and ask prices. In this section we explain in greater detail the structures of these two markets, and more specifically, the structure of the securities that are of interest to this paper.

Participants in the LOTC comprise market-making members and ordinary members. Major international banks make up 12 of the 13 market-making members and are required by the London Bullion Market Association (LBMA) to provide two-way quotes during London market hours, and whenever the New York market is closed. Ordinary members comprise companies that are operational in areas that are closely related to the physical gold itself, including trading, broking, shipping and storage, mining, refining, inspection and assaying and research. Trading occurs between members of both types. This membership restriction leads to a market with few highly specialized participants representing clients internationally. In 2011, there were 56 full members in this market (Murray, 2011).

The usual minimum transaction size is 2,000 fine troy ounces for gold (LBMA, 2014), and typical transactions between market makers are 5,000 ounces. Quotes are in US dollars per 
fine troy ounce with a minimum tick size of one cent. Fine gold content represents the true quantity of gold in a bar, which may be less than the total bar weight due to impurities.

Transparency in the LOTC market is low. There is no public record of trade volumes or prices, only the quotes are observable. The lack of transparency is the major motivation of the Loco London Liquidity Survey (Murray, 2011) which endeavors to show that gold is a "high quality liquid asset". The only figures published on a regular basis by the LOTC market are monthly clearing statistics, based on returns from the six clearing members that form the London Precious Metals Clearing Company. The LOTC does not require its members to report turnover and other related statistics. There are no major structural changes to the LOTC market during our sample period that would have a large impact on price discovery.

COMEX is a futures exchange that trades many commodities. Individuals and firms can trade and membership requirements are less stringent than the LOTC. Requirements for individual membership include good moral character and business integrity (CME Group, 2014e). Corporate membership is open to various company types and requires some ownership stake in the equity of the exchange.

Each gold futures contract on COMEX represents 100 troy ounces (CME Group, 2014a) and is quoted in US dollars per troy ounce. Delivery takes place on any business day within the delivery month, but not later than the last business day of the delivery month. Gold delivered under this contract needs to meet the 995 minimum fineness requirements. Minimum tick size on these contracts is 10 cents per troy ounce.

Most volume in the COMEX gold futures market is in contracts that are marked Trading At Settlement (TAS). TAS allows traders to commit to a trade without knowing the price at which it will settle. A trader submits an order at any time, with this order matched to a countering order. The trade is finally settled at the settlement price which is determined by the exchange at 13:30 Eastern Time. This method essentially allows for a trade to occur at a price that is determined in the future. On the one hand, this added uncertainty allows uninformed liquidity traders to trade on a more equal level with the informed, as neither party should know what the final settlement price will be. Informed traders can use TAS in order to arbitrage any intraday price deviations. With sufficient informed trade, the price at any time should be indicative of the future settlement price. TAS orders are only available on five contract months, deemed Active Months (CME Group, 2014b). These months are February, April, June, August 
and December, representing every two months except for a break in October. In any given month, the most actively traded contract is the one closest to expiry.

Transparency in the COMEX futures market is much greater than in the LOTC. Although traders are anonymous, bid and ask depth is available for ten price levels. Partially hidden iceberg orders are also available, with each addition to the visible part of the order being placed at the bottom of the queue in the order book (CME Group, 2014d).

Although there have been many structural changes to COMEX, only a small number have changed the way gold futures trade. From the start of our sample period in 1997 to December 3, 2006, gold futures on COMEX traded on the floor during floor hours only and on the NYMEX electronic trading platform outside of floor hours only. From December 3, 2006, these contracts commenced trading on the GLOBEX platform, which has lower latency and more accessibility to international traders. Along with this shift, electronic trading hours were extended to overlap floor hours, allowing concurrent trading on the floor and GLOBEX platform. We treat this change as a structural break and analyze how it affects the location of price discovery. Although there are a few other latency-related changes during our sample period, these do not have a meaningful impact on the way trade occurs in this market.

Overall, the wholesale nature of the LOTC market is very different to the open retail exchange system available through COMEX. With major differences in products, trade sizes, centrality and participants, we expect that the contributions to price discovery of the New York futures and London spot markets come from different sources. These two markets constitute an interesting cross-border environment in which to study the price discovery of gold.

\section{Data}

This study compares futures contracts traded on COMEX and gold spot quotes from LOTC. Since accurate estimation of price discovery shares can only be achieved through the use of very high frequency data, we use trade and quote data sampled at a one-second frequency. Our sample period extends from January 1, 1997 to November 30, 2014. In total this includes 3,872 trading days and 51,702,414 one-second observations.

We obtain intraday and trade and quote data for the futures contracts and the LOTC market from Thomson Reuters Tick History. Our data include the best (inside) bid and ask quotes in each market, time-stamped to the millisecond. From the best bid and ask quotes, we calculate 
the midquote (the simple average of the bid and ask quotes at that point in time), which reduces the effects of bid-ask bounce. Using these data, we identify the most actively traded futures contract for any given day, illustrated in Table I. The contracts are deliverable on any day within their expiry month. Consequently, contracts are not very actively traded within their delivery period. For example, because a February contract is deliverable on any business day in February, it is no longer actively traded during February. Intuitively, contract holders would like to take delivery as early as possible to collect their returns. We find that volume shifts to the next active contract two days before the current contract becomes deliverable. For example, the most traded contract in January is the one closest to expiry (the February contract); however, on the last two days of January, volume shifts to the next active contract (the April contract). On this basis, we create a futures price series that uses the most actively traded contract at every point in time. This price series is converted into a one-second sampled time series. Similarly, we convert the intraday quotes for the LOTC gold spot market to one-second increments. The two midquote series are merged by date and time, resulting in one time series of two prices.

\section{< Insert Table I here >}

Because the LOTC gold spot market and the COMEX futures market both trade almost 24 hours per day, there is ample overlap between their trading times. COMEX gold futures trade in an electronic exchange setting from Sunday to Friday, with a break from 17:15 to 18:00 New York time. The LOTC on the other hand allows continuous trading through their inter-office telephone service in an OTC setting, with indicative quotes from members available at all times. Summer and winter time changes in the US change the concurrent trading time of the two markets. New York time shifts between -4h GMT and -5h GMT. Converting the COMEX break period to GMT yields $21: 15$ to $22: 00$ in summer and 22:15 to 23:00 in winter. To simplify calculation and ensure both markets trade concurrently for the entire sample, we eliminate all trades and quotes after 20:00 GMT. This also eliminates a short period of time around the opening and closing of COMEX, consistent with the approach taken in other intraday microstructure studies.

We extract data on macroeconomic announcements for both the UK and US from Bloomberg. The data include the announcement content and announcement time-stamp for major 
economic announcements including GDP, central bank target rate, employment figures (including Non-Farm Payroll for US), PPI, and CPI.

The gold spot market is large, with most trades occurring in LOTC market. Due to the nature of OTC markets, trade volumes are not reported making it difficult to measure the size of the gold spot market. Table II illustrates the trade in gold in each of the six major gold trading countries. These estimates are sourced from Lucey et al. (2013) (who use Murray (2011) and GFMS Ltd. (2012) data) and reflect trading in all gold-related instruments (including spot and gold derivatives).

\section{< Insert Table II here >}

Table II illustrates that the UK accounts for approximately $87 \%$ of the combined volume of gold trading in the six main gold trading countries, with $90 \%$ of this being in the spot market. According to the Loco London Liquidity Survey (Murray, 2011), the daily turnover on the London gold spot market alone is in excess of $\$ 216$ billion, which is comparable in value to USAustralian and US-Canadian dollar foreign exchange settlements (based on 2010 data in Bank for International Settlements, 2011), as well as the daily turnover of all stock exchanges in the world combined. The average daily dollar volume of our selected futures contract over the same period is approximately $\$ 22$ billion, illustrating the size disparity between our markets.

\section{Method}

Our aim in this paper is to analyze where information enters the gold market, and how this has changed over time. We begin with two measures that are widely used in the price discovery literature, namely the Hasbrouck (1995) Information Share (IS) and the Gonzalo and Granger (1995) Component Share (CS). Fundamentally, both $I S$ and $C S$ decompose price innovations into permanent and temporary components. They are estimated using a Vector Error Correction Model (VECM):

$$
\begin{aligned}
& \Delta p_{1, t}=\alpha_{1}\left(p_{1, t-1}-p_{2, t-1}\right)+\sum_{i=1}^{200} \gamma_{i} \Delta p_{1, t-i}+\sum_{j=1}^{200} \delta_{j} \Delta p_{2, t-j}+\varepsilon_{1, t} \\
& \Delta p_{2, t}=\alpha_{2}\left(p_{1, t-1}-p_{2, t-1}\right)+\sum_{k=1}^{200} \varphi_{k} \Delta p_{1, t-k}+\sum_{m=1}^{200} \phi_{m} \Delta p_{2, t-m}+\varepsilon_{2, t}
\end{aligned}
$$

where $\Delta p_{i, t}$ is the change in the $\log$ price $\left(p_{i, t}\right)$ of the asset traded in market $i$ at time $t$. Appendix A outlines the calculation of $I S$ and $C S$ from the VECM model above. We estimate the 
VECM and the price discovery measures separately for each day in the sample period (avoiding the need to deal with periods of market closure) and each hourly interval in the sample.

Recent studies of price discovery measures show that IS and CS both are sensitive to the relative level of noise between two markets - they measure a combination of leadership in impounding new information (what price discovery metrics aim to measure), and the relative level of noise in the price series (Yan \& Zivot, 2010; Putninšs, 2013). Consequently, IS and CS tend to overstate the price discovery contribution of the less noisy market. Of the two, IS places greater weight on the speed at which a price series impounds new information, compared to the $C S$ metric which is a measure of the relative levels of noise. It is likely that the levels of noise in the prices of the two markets examined in this paper are vastly different considering their differences in liquidity, market structure and instrument types. Therefore, it is important to keep in mind the sensitivity of $I S$ and $C S$ to differences in microstructure noise when interpreting the results.

An important insight of the recent price discovery literature is that a combination of $I S$ and $C S$ is able to correctly attribute contributions to price discovery without being influenced by differences in noise levels. $I S$ and $C S$ can be combined in such a way that their dependence on noise cancels out. This measure, known as the Information Leadership Share $(I L S)$, developed in Yan and Zivot (2010) and Putniņš (2013), is calculated as follows:

$$
I L S_{1}=\frac{\left|\frac{I S_{1} C S_{2}}{I S_{2} C S_{1}}\right|}{\left|\frac{I S_{1} C S_{2}}{I S_{2} C S_{1}}\right|+\left|\frac{I S_{2} C S_{1}}{I S_{1} C S_{2}}\right|}, \quad I L S_{2}=\frac{\left|\frac{I S_{2} C S_{1}}{I I 1_{1} C S_{2}}\right|}{\left|\frac{I S_{1} C S_{2}}{I S_{2} C S_{1}}\right|+\left|\frac{I S_{2} C S_{1}}{I S_{1} C S_{2}}\right|}
$$

We estimate all three price discovery metrics, noting that they measure different aspects of price discovery. ILS measures the relative speed at which a market reflects new information and therefore is informative about where information first enters the market; higher values of ILS for a market indicate the market is more often the first to reflect new information. In contrast, $C S$ and $I S$ contain incremental information about the relative amount of noise in one market's prices compared to those of the other market; higher $I S$ and $C S$ for a market indicate its prices are relatively less noisy. 


\section{Results}

\subsection{Daily results}

We estimate the price discovery measures for each trading day in our sample period using a one-second sampling frequency. Table III reports the annual averages of the daily price discovery shares for the futures market (the spot market price discovery shares are simply one minus the futures market share), and Figure 1 illustrates the trends through time using a 180-day moving average. ${ }^{6}$ The $I S$ and $C S$ measures at the start of the sample are only slightly above $50 \%$ (67\% and 61\%, respectively). CS rises steadily until 2006, after which it remains consistently above $90 \%$. IS also increases sharply after 2006 and remains very high for the remainder of the sample period.

$I L S$ tells a slightly different story. The futures market in the first year of our sample has an ILS of $66 \%$, which rises above $80 \%$ for the years 2002 to 2007, after which it falls slightly and remains stable around $66 \%$. Due to its insensitivity to differences in noise, the ILS estimates paint the clearest picture of trends in impounding new information. It indicates that in each of the past 17 years, the futures market has been a more important source of gold price discovery than the UK spot market and that its contribution has fluctuated since the start of the sample. The fact that $I S$ and $C S$ tend to increase sharply after 2006 and this increase is not reflected in ILS suggests that after 2006 the futures market experienced a substantial decline in the relative amount of noise in its prices compared to the spot market.

\section{$<$ Insert Table III here > \\ < Insert Figure 1 here >}

Such a distinct change in the price discovery metrics begs further explanation. The change occurs at the end of 2006 and is statistically significant controlling for other factors (regressions results reported in Section 5.3). The likely cause is a substantial change in the structure of trading at COMEX during the last two months of 2006. At this time COMEX opened

\footnotetext{
${ }^{6}$ The moving average smooths the day-to-day variation in price discovery shares, allowing one to see the differences in the mean levels of price discovery. In Table III, we show that the price discovery shares are statistically different to 0.50 , indicating that the day-to-day variance does not impede our ability to identify where price discovery occurs on average.
} 
electronic trading alongside floor trading. Before the change, the bulk of the trading volume on COMEX was generated by the trading floor in an open outcry system. Outside of the floor hours, COMEX used NYMEX's Access electronic trading platform with floor and electronic hours not overlapping (Morrison, 2006). The extended trading hours of the electronic platform were primarily to stay competitive with other exchanges that were providing electronic trading at this time (Goodman, 2011). At the same time, COMEX adopted the GLOBEX platform, providing near 24-hour electronic trading, internationally, with low latency. The move to an international electronic exchange was complemented by an international incentive program that allowed traders outside the US to trade at lower costs (CME Group, 2014c).

Beginning on December 3, 2006, COMEX also expanded its metals electronic trading to include side-by-side trading of Asian and London metals futures contracts (CME Group Media Room, 2014). Parallel trading of international futures contracts is likely to have enhanced the attractiveness of COMEX.

The changes in the structure of the COMEX at the end of 2006 flow through to the volume of contracts traded. Figure 2 illustrates the daily average traded volume for the most active contract at every point in time. ${ }^{7}$ There is a clear increase in the traded volume on COMEX per contract during the sample period, and in particular, a stark increase after the changes at the end of 2006. Intuitively, greater volume leads to greater liquidity and lower spreads, resulting in less noisy prices and higher values of $I S$ and $C S$, as is evident in our results.

\section{$<$ Insert Figure 2 here >}

The increase in futures market volume is also likely to affect the average bid-ask spread. Figure 3 illustrates a moving average of the spreads in each of the two markets during our sample period. There is a distinct reduction in the spread of COMEX at the end of 2006. Interestingly, at the same time, there is a corresponding increase in the spread of LOTC, suggesting that perhaps some of the volume from LOTC migrated to COMEX after the upgrade of the COMEX platform and implementation of international incentive programs. Unfortunately, due to the absence of a time series of LOTC volumes we are unable to further investigate this

\footnotetext{
${ }^{7}$ Our data from Thomson Reuters Tick History are unable to separate COMEX trades into those executed on the floor versus those executed in their electronic system.
} 
conjecture. ${ }^{8}$ At many times the futures market spread is constrained by its minimum tick size of ten cents. The LMBE however is not limited by its minimum tick size of one cent.

\section{$<$ Insert Figure 3 here >}

The evidence in this section shows that the New York COMEX futures market provides the greater share of gold price discovery throughout our sample period. The change in the market structure of COMEX at the end of 2006 led to significant changes in the global gold market. A more accessible, electronic 24-hour market with low costs and fast execution increased the volume and liquidity of COMEX, decreasing the relative amount of noise in COMEX prices relative to those of the LOTC.

\subsection{Intraday results}

In this section we examine intraday patterns in price discovery by estimating the three price discovery metrics in each hour of each day. Hourly observations allow us to examine the effect of time zone on price discovery. London is either four or five hours ahead of New York, depending on the time of year. Consequently, for up to five hours of the London working day, New York may not yet have started work, and at the end of the day, London would finish work five hours before New York.

The difference in London and New York time zones raises the interesting question of whether the US futures market leads price discovery even when most of the local population is asleep? In other words, is there a tendency for informed investors to be more active in their domestic market during daylight hours? Our results indicate that this is the case in the earlier years of our sample, but not in more recent years. Figure 4 illustrates the average intraday price discovery measures each hour for a few indicative years. The years 1998 and 2005 are representative of the intraday trends for all other years in between - this is the period before the trading platform upgrades in COMEX. Similarly, 2007 and 2013 are representative of the intraday trends from 2007 onwards, after the market structure change.

\footnotetext{
${ }^{8}$ The absence of data on LOTC volume also means that we are unable to calculate liquidity measures for this market.
} 


\section{$<$ Insert Figure 4 here >}

Figure 4 shows that at the beginning of the sample, there is a distinct pattern in price discovery throughout the day. The opening of floor trading at COMEX around 13:20 GMT (12:20 GMT) is associated with a substantial increase in the price discovery share of the futures market. This increase reverses when floor trading ends at 18:30 GMT (17:30 GMT). In other words, the intraday period during which the COMEX floor is open is associated with substantially more price discovery occurring in the US.

From 2007 onwards, after COMEX introduced the near 24-hour electronic GLOBEX platform, the intraday patterns are substantially different. There are no longer clear intraday patterns in the price discovery shares and instead the price discovery shares remain relatively stable throughout the day. The impact of the floor opening hours is no longer present from 2007. Daylight or working hours no longer affect the location of price discovery.

\subsection{Determinants of price discovery}

In this section we test various determinants of gold price discovery shares, adding multivariate statistical evidence to support the casual observations made in previous sections. We also examine whether different types of macroeconomic news tend to be impounded in one or the other market. To do this, we estimate time-series regressions in which the dependent variable is the futures market's (COMEX) share of gold price discovery, measured each hour. A positive coefficient for an independent variable signifies that variable increases the future market's share of price discovery. Using the high frequency (hourly) estimates of price discovery allows us to investigate intraday effects such as time zones, gold price fixings and news announcements.

Our choice of variables is driven by the prior literature as well as our reasoning about factors that could influence the location of price discovery. The London Gold Fixing is an important determinant of the gold price (Caminschi \& Heaney, 2014). The AM and PM fixings occur daily at 10:30am and 3:00pm UK time, respectively. ${ }^{9}$ We include two dummy variables, AMFIX and PMFIX, that equal one during the hour of the AM and PM London gold price fixing

\footnotetext{
${ }^{9}$ Our data end before the commencement of the new benchmark price mechanism set by the LBMA as an improvement on the traditional fix. See http://www.lbma.org.uk/lbma-gold-price for an explanation of the new price setting approach.
} 
and zero otherwise. ${ }^{10}$ We include dummy variables for a set of announcements shown in previous studies to affect the price of gold and other precious metals (Batten et al., 2010; Cai et al., 2001; Christie-David et al., 2000; Elder et al., 2012). The announcements include central bank rate announcements and major macroeconomic news such as GDP, employment, PPI and CPI. The dummy variables UKRATE and USRATE equal one during hourly periods that contain announcements from UK and US central banks regarding target interest rates. Similarly UKEMPLOY and USEMPLOY are dummy variables for national employment announcements in the UK and US. UKGDP, USGDP, UKPPI, USPPI, UKCPI, and USCPI are dummy variables for GDP, PPI and CPI announcements made by the UK and US. With all of the dummy variables, if the announcement occurs on the hour the dummy variable is equal to one for the hourly interval that starts with the announcement, consistent with our approach for the PMFIX variable.

To formally test the effects of the market structure changes in COMEX at the end of 2006, we include a dummy variable, POST, which is equal to one after the introduction of the GLOBEX trading platform. To account for the intraday trends reported in the previous section, we include three dummy variables, ASIA, USA and UK, which equal to one when the Hong Kong Stock Exchange, New York Stock Exchange, and London Stock Exchange are trading, respectively. These dummy variables are proxies for the business hours in the region; we do not expect stock market activity per se to influence gold price discovery. Finally, we include variables that measure the liquidity in each of the markets: FTRSPREAD and SPOTSPREAD are the time-weighted average bid-ask spreads in the COMEX and LOTC markets, respectively.

\section{< Insert Table IV here >}

Table IV reports the regression results. The dependent variables are hourly price discovery estimates $(C S, I S$, and $I L S)$ for the futures market and the independent variables are the determinants of price discovery described above. ${ }^{11}$ We calculate $t$-statistics using Newey-West corrected standard errors. Model lincludes all the determinants of price discovery, Model 2 adds

\footnotetext{
${ }^{10}$ Our units of observation are hourly intervals, so AMFIX=1 for the hourly interval 10am-11am and PMFIX=1 for the hourly interval $3 \mathrm{pm}-4 \mathrm{pm}$.

${ }^{11}$ Unlike Figure 1, the hourly price discovery estimates used in the regressions do not use a moving average.
} 
interaction of POST and the time zone dummy variables, and Model 3 adds all interactions between POST and the determinants of price discovery.

The COMEX trading platform upgrade (POST) has a highly significant, positive effect on all price discovery measures (with exception of the ILS in Model 1). According to Model 1, CS, $I S$, and $I L S$ increase by $16 \%, 17 \%$, and $0 \%$, respectively after the change, holding other variables constant. These multivariate results support our earlier observations that the platform upgrade increased the relative liquidity of COMEX, thereby decreasing the amount of noise in COMEX prices (hence the increase in $C S$ and $I S$ ), but did not have a large impact on the relative speed at which the futures market reflects new information (no significant change in $I L S$ ). The other regressions support this result with the POST coefficient for the ILS regressions remaining relatively small compared to the $C S$ and $I S$ regressions.

The variables measuring business hours in the three regions, ASIA, USA and UK, are statistically significant determinants of the intraday price discovery shares. The coefficients for USA and UK are positive, indicating that on average across the whole sample period the futures market increases its contribution to price discovery during US and UK business hours. For example, Model 1 implies that ILS is on average (across the full sample) 3\% and 4\% higher during US and UK business hours, ceteris paribus. The intraday patterns in price discovery change significantly after the upgrade and internationalization of COMEX (as we noted earlier in Figure 4). For the $I L S$ regressions, the coefficient on the interaction of POST with the USA and UK dummy variables is negative and significant, largely negating the intraday pattern that existed before the upgrade of COMEX. For example, Model 2 indicates that before the upgrade, ILS is 6\% higher during US business hours and 6\% higher during UK business hours, whereas after the upgrade, it is only $2 \%$ (6\% minus $4 \%$ ) higher during US business hours and $1 \%(6 \%$ minus 5\%) higher during UK business hours. For the ILS regressions, the coefficients associated with ASIA indicate that during Asian business hours, relatively less price discovery occurs in the futures market before the upgrade of COMEX, and that the upgrade attenuates this intraday pattern. Overall, these results show a general movement toward a more globalized gold market after the microstructure change, with diminishing importance of regional time zones.

The liquidity of both COMEX and LOTC (measured by their bid-ask spreads) has a significant impact on where and how price discovery occurs. Both $I S$ and $C S$ tend to be higher for markets that have less noisy prices. This tendency can be seen in the regressions with the 
large negative coefficients for FTRSPREAD and positive coefficients for SPOTSPREAD, indicating that a decrease in the relative liquidity of COMEX compared to the spot market (either wider spreads on COMEX or narrower spreads in the spot market) is associated with lower futures market $I S$ and $C S$. The $I L S$ regressions indicate that more price discovery occurs in the futures market when it is relatively more liquid, i.e., when the futures market spread is narrower or the spot market spread is wider. Because ILS is unaffected by the level of noise, the results from the $I L S$ regressions suggest that informed traders prefer to trade in the more liquid market. This tendency is driven by the period before the COMEX upgrade, after which ILS is no longer positively associated with liquidity. One possibility is that informed traders become less sensitive to relative liquidity once it is plentiful.

Although the UK gold fixing is known to affect the price of gold, its effect on the location of price discovery is relatively modest. In the ILS regressions, the AMFIX coefficient is significantly negative suggesting that around the AMFIX the LOTC market increases in the speed at which it reflects new information (a decrease in the relative speed of the futures market). This effect is attenuated by the upgrade to COMEX. The PMFIX coefficients for the CS and $I S$ regressions are highly significant and positive, yet there is no significance in the ILS regressions, indicating that immediately after the PM fix the LOTC market becomes relatively noisier than the futures market.

The effect of macroeconomic announcements varies across the different announcement types. Arguably, the most important announcement in our sample is the US GDP announcement, which is reflected in the significance and size of the coefficients for this variable (across all price discovery measures). The negative coefficient of USGDP in the IS and CS regressions suggests an increase in the relative noise of futures market quotes around US GDP announcements, while the positive coefficient in the ILS regressions indicates that around US GDP announcements, the US futures market takes on an even more important role in gold price discovery. In other words, much of the trading on US GDP news is likely to occur in the futures market, making it both faster to reflect the new information and noisier around such announcements. Interestingly, the significant changes in the location of price discovery around US GDP announcements are largely attenuated after the upgrade and internationalization of COMEX.

Similar to the US GDP result, in CS regressions, the coefficient for USEMPLOY is large, negative and highly significant, indicating an increase in noise in the futures market. The last 
noteworthy result in Table IV is the UKCPI variable. The increases in futures market $I S$ and $C S$ are both large and highly significant (with no corresponding increase in $I L S$ ), indicating UK CPI announcements tend to be associated with a relative decrease in futures market noise or a relative increase in spot market noise.

In these regressions, the intercept is not very meaningful, representing a very small subset of the data. It represents the time period between 0:00 GMT and 1:00 GMT when there are no announcements, before the COMEX upgrade, and with hypothetical zero bid-ask spreads in both markets.

Overall the results indicate that although many factors affect the location of price discovery in the gold market, the upgrade of COMEX to a 24-hour electronic low latency platform with incentives for international participation causes many of these effects to diminish. This finding reflects greater globalization of international gold trade, with the traders' choice of markets being driven by market structure, as opposed to market location.

\subsection{Robustness tests}

In this section we assess the robustness of the results. We test the sensitivity of the results to the choice of lag length as well as different forms of the dependent and independent variables used in our regressions. Overall the results are qualitative unchanged in the robustness tests and do not change our overall conclusions.

The baseline models use 200 lags in the VECM as this should be sufficient to allow markets to reach equilibrium after a price change in one market. The decision to use 200 lags is somewhat arbitrary, so for robustness we use the Akaike Information Criterion (AIC) to select the optimal lag structure. We estimate a VECM with various lag lengths and compare the AIC across individual days and hours for a small randomly selected group of days. Taking the median suggests that 460 lags is the optimal lag length. We re-estimate all of our results using 460 lags in the VECM. Table V reports results from the re-estimated regressions.

\section{$<$ Insert Table V here >}

Overall our results are robust to the increased lag length, and although our conclusions remain the same there are a few minor changes to the coefficients in our regressions. First, the 
effect of POST in the ILS regressions is negative but remains small, confirming that the COMEX platform upgrade did not have a large impact on the futures market's contribution to impounding new information. Second, the coefficient on FTRSPREAD*POST in ILS regression Model 3 is larger, suggesting that an increase in the COMEX spread after the microstructure change increases this market's share of price discovery. Third, some of the coefficients for the London Gold Fixings change in significance; however our interpretation does not, with coefficients remaining small and suggesting only a modest impact on the location of price discovery.

Many macroeconomic announcements simply confirm analyst expectations and thus do not result in much, if any, surprise. To test whether unexpected announcements have a different effect to announcements in general, we re-estimate the Table IV regressions using announcement surprise instead of simple announcement times. In this case our dummy variables are equal to one if the announced change in the macroeconomic variable is contrary to analyst expectations as measured by the Bloomberg Analyst Survey. We find that our original results are robust to this specification. $^{12}$

The final robustness test that we conduct is with the dependent variables. Instead of using the level of price discovery, we use the change in price discovery over the previous hour. This addresses concerns about the stationarity of the price discovery shares. We find that results are similar to our original specification.

Overall our results are robust to lag lengths, whether the outcome of an announcement is a surprise, and using first differences of the dependent variable.

\section{Conclusion}

This paper investigates price discovery in the global gold market using high-frequency data for the period 1997 to 2014. The gold market is of interest to both researchers and industry due to its immense size and economic importance.

Our first major finding is that the US futures market contributes more to price discovery compared to the London OTC spot market, despite being ten times smaller. This result indicates that market structure and instrument type is of greater importance than market size and liquidity. The finding supports the idea that the futures market's key features of centralization, relative

\footnotetext{
${ }^{12}$ For conciseness these results are not reported, but are available from the authors upon request.
} 
transparency, inbuilt leverage, and ability to avoid dealing with the underlying asset, contribute to its disproportionately large role in price discovery.

Our second key finding reinforces the importance of market structure on the process of price discovery. Changes in the US gold futures market from a floor-based system to the nearly 24-hour, fully electronic low latency GLOBEX platform is associated with a considerable decrease in noisiness of prices in this market, but no increase in the relative speed with which the market reflects new information.

Our third key finding is that several factors affect the location of price discovery. Price discovery shares vary substantially at both daily and intraday levels. Prior to the futures market's upgrade to the GLOBEX platform, the location of price discovery is largely dictated by daylight hours within each locale, with the US futures market contributing more to price discovery during US daylight hours. After the move to the GLOBEX platform and introduction of international participation incentives in the futures market, intraday price discovery variation declines with US futures taking a consistent lead irrespective of market hours. This decline illustrates how a market structure that is more accessible internationally can negate the importance of geographic location and create a more integrated global market.

Our findings carry important implications for market design. We show that market structure is of greater importance to price discovery than market size and liquidity. Changes to market structure can have opposite effects on the speed at which prices reflect new information and accuracy with which they reflect the information (amount of noise), as is the case in the market structure change that we examine. Market designers can improve the efficiency of their markets by carefully considering the structures they implement, as this can have greater impact than methods focused simply on increasing turnover and participation.

There are many avenues left open for future research. Markets are implementing new structural changes on a continual basis; other structural changes in the gold market may have a different effect on price discovery. Further, gold mining volumes are small compared to holdings, meaning that gold is more decentralized than many other commodities that are consumed. This market allows for research into the centralization of markets. Although many markets are becoming more decentralized, the gold market seems to be moving in the opposite direction. The effect of the new benchmark process for the gold price (introduced in 2015) also remains unclear. If the new process increases transparency, as it is designed to do, it should 
result in a move back towards the LOTC market as a price setter. Finally, it will be interesting to see whether the conclusion of the COMEX International Incentive Program on December 31, 2015 will have any effect on the price discovery shares for the gold market. This program provides lower cost trading to traders outside the US. 


\section{APPENDIX A: Calculation of Component Shares (CS) and Information Shares (IS)}

We estimate the $I S$ and $C S$ metrics using the error correction parameters and variancecovariance of the error terms from equation (1) and (2) as in Baillie et al. (2002). The component shares are obtained from the normalized orthogonal to the vector of error correction coefficients, $\alpha_{\perp}=\left(\gamma_{1}, \gamma_{2}\right)^{\prime}$, thus:

$$
C S_{1}=\gamma_{1}=\frac{\alpha_{2}}{\alpha_{2}-\alpha_{1}}, \quad C S_{2}=\gamma_{2}=\frac{\alpha_{1}}{\alpha_{1}-\alpha_{2}}
$$

Given the covariance matrix of the reduced form VECM error terms,

$$
\Omega=\left(\begin{array}{cc}
\sigma_{1}^{2} & \rho \sigma_{1} \sigma_{2} \\
\rho \sigma_{1} \sigma_{2} & \sigma_{2}^{2}
\end{array}\right)
$$

and its Cholesky factorization, $\Omega=M M^{\prime}$, where

$$
\mathrm{M}=\left(\begin{array}{cc}
m_{11} & 0 \\
m_{12} & m_{22}
\end{array}\right)=\left(\begin{array}{cc}
\sigma_{1} & 0 \\
\rho \sigma_{2} & \sigma_{2}\left(1-\rho^{2}\right)^{1 / 2}
\end{array}\right)
$$

we calculate the IS using:

$$
I S_{1}=\frac{\left(\gamma_{1} m_{11}+\gamma_{2} m_{12}\right)^{2}}{\left(\gamma_{1} m_{11}+\gamma_{2} m_{12}\right)^{2}+\left(\gamma_{2} m_{22}\right)^{2}}, \quad I S_{2}=\frac{\left(\gamma_{2} m_{22}\right)^{2}}{\left(\gamma_{1} m_{11}+\gamma_{2} m_{12}\right)^{2}+\left(\gamma_{2} m_{22}\right)^{2}}
$$

Because $I S$ is impacted by the order of the price series in the Cholesky factorization, we calculate $I S$ under each of the potential orderings and take the simple average, as per Baillie et al. (2002). 


\section{References}

Aggarwal, R., \& Lucey, B. M. (2007). Psychological barriers in gold prices? Review of Financial Economics, 16, 217-230.

Anand, A., Gatchev, V. A., Madureira, L., Pirinsky, C. A., \& Underwood, S. (2011). Geographic proximity and price discovery: Evidence from NASDAQ. Journal of Financial Markets, 14, 193-226.

Ates, A., \& Wang, G. H. (2005). Information transmission in electronic versus open-outcry trading systems: An analysis of US equity index futures markets. Journal of Futures Markets, 25, 679-715.

Baillie, R. T., Booth, G. G., Tse, Y., \& Zabotina, T. (2002). Price discovery and common factor models. Journal of Financial Markets, 5, 309-321.

Bank for International Settlements (2011) Triennial Central Bank Survey. Report on global foreign exchange market activity in 2010. December 17, 2014. Available at http://www.bis.org/press/p101201.htm

Batten, J. A., Ciner, C., \& Lucey, B. M. (2010). The macroeconomic determinants of volatility in precious metals markets. Resources Policy, 35, 65-71.

Baur, D. G., \& McDermott, T. K. (2010). Is gold a safe haven? International evidence. Journal of Banking \& Finance, 34, 1886-1898.

Baur, D. G., \& Lucey, B. M. (2010). Is gold a hedge or a safe haven? An analysis of stocks, bonds and gold. Financial Review, 45, 217-229.

Bohl, M. T., Salm, C. A., \& Schuppli, M. (2011). Price discovery and investor structure in stock index futures. Journal of Futures Markets, 31, 282-306.

Boyd, N., \& Locke, P. (2014). Price discovery in futures and options markets. Journal of Futures Markets, 34, 853-867.

Cabrera, J., Wang, T., \& Yang, J. (2009). Do futures lead price discovery in electronic foreign exchange markets?. Journal of Futures Markets, 29, 137-156.

Cai, J., Cheung, Y. L., \& Wong, M. (2001). What moves the gold market?. Journal of Futures Markets, 21, 257-278.

Caminschi, A., \& Heaney, R. (2014). Fixing a leaky fixing: Short-term market reactions to the London PM gold price fixing. Journal of Futures Markets, 34, 1003-1039. 
Capie, F., Mills, T. C., \& Wood, G. (2005). Gold as a hedge against the dollar. Journal of International Financial Markets, Institutions and Money, 15, 343-352.

Christie-David, R., Chaudhry, M., \& Koch, T. W. (2000). Do macroeconomics news releases affect gold and silver prices?. Journal of Economics and Business, 52, 405-421.

CME Group (2014a). Gold futures contracts specs. January 14, 2015. Available at http://www.cmegroup.com/trading/metals/precious/gold_contract_specifications.html

CME Group (2014b). Gold futures daily settlement procedure. January 14, 2015. Available at http://www.cmegroup.com/trading/metals/files/daily-settlement-procedure-goldfutures.pdf

CME Group (2014c). International Incentive Program (IIP) questions and answers. January 14, 2015. Available at http://www.cmegroup.com/company/membership/files/InternationalIncentiveProgramQA .pdf

CME Group (2014d). The world's leading electronic platform. CME GLOBEX. January 14, 2015. Available at http://www.cmegroup.com/globex/files/globexbrochure.pdf

CME Group (2014e). Types of membership. January 14, 2015. Available at http://www.cmegroup.com/company/membership/types-of-membership-nymex.html

CME Group Media Room (2014). NYMEX to offer COMEX metals side by side, miNYs beginning on December 3. December 18, 2014. Available at: http://cmegroup.mediaroom.com/index.php?s=43anditem $=954$

Dolatabadi, S., Nielsen, M. Ø., \& Xu, K. (2015). A fractionally cointegrated VAR analysis of price discovery in commodity futures markets. Journal of Futures Markets, 35, 339-356.

Elder, J., Miao, H., \& Ramchander, S. (2012). Impact of macroeconomic news on metal futures. Journal of Banking \& Finance, 36, 51-65.

Frino, A., Mollica, V., \& Webb, R. I. (2014). The impact of co-location of securities exchanges' and traders' computer servers on market liquidity. Journal of Futures Markets, 34, 20-33.

Fuangkasem, R., Chunhachinda, P., \& Nathaphan, S. (2014). Information transmission among world major gold futures markets: Evidence from high frequency synchronous trading data. Journal of US-China Public Administration, 11, 255-269.

GFMS Ltd. (2012). Gold survey 2012, GFMS Ltd., London. 
Gonzalo, J., \& Granger, C. (1995). Estimation of common long-memory components in cointegrated systems. Journal of Business \& Economic Statistics, 13, 27-35.

Hasbrouck, J. (1995). One security, many markets: Determining the contributions to price discovery. Journal of Finance, 50, 1175-1199.

Hautsch, N., Hess, D., \& Veredas, D. (2011). The impact of macroeconomic news on quote adjustments, noise, and informational volatility. Journal of Banking \& Finance, 35, 27332746.

Hillier, D., Draper, P., \& Faff, R. (2006). Do precious metals shine? An investment perspective. Financial Analysts Journal, 62, 98-106.

Goodman, L.M. (2011). The asylum: The renegades who hijacked the world's oil market. William Morrow.

Lin, H. N., Chiang, S. M. \& Chen, K. H. (2008). The dynamic relationships between gold futures markets: evidence from COMEX and TOCOM. Applied Financial Economics Letters, 4, $19-24$.

LBMA (2014). Market tools. January 14, 2015. Available at: http://www.lbma.org.uk/markettools

Lucey, B. M., Larkin, C., \& O'Connor, F. A. (2013). London or New York: Where and when does the gold price originate?. Applied Economics Letters, 20, 813-817.

Morrison, K. (2006). COMEX considers parallel trading. Financial Times, published April 7, 2006.

Murray, S. (2011). Loco London liquidity survey. Alchemist, 63, 9-10.

O'Callaghan, G. (1991). The Structure and Operation of the World Gold Market. IMF, New York.

Putniņš, T.J. (2013). What do price discovery metrics really measure? Journal of Empirical Finance, 23, 68-83.

Rosenberg, J. V., \& Traub, L. G. (2009). Price discovery in the foreign currency futures and spot market. Journal of Derivatives, 17, 7-25.

Sherman, E. J. (1982). Gold: a conservative, prudent diversifier. The Journal of Portfolio Management, 8, 21-27. 
Xu, X. E. \& Fung, H.G. (2005). Cross-market linkages between US and Japanese precious metals futures trading. Journal of International Financial Markets, Institutions and Money, 15, 107-24.

Yan, B., \& Zivot, E. (2010). A structural analysis of price discovery measures. Journal of Financial Markets, 13, 1-19. 


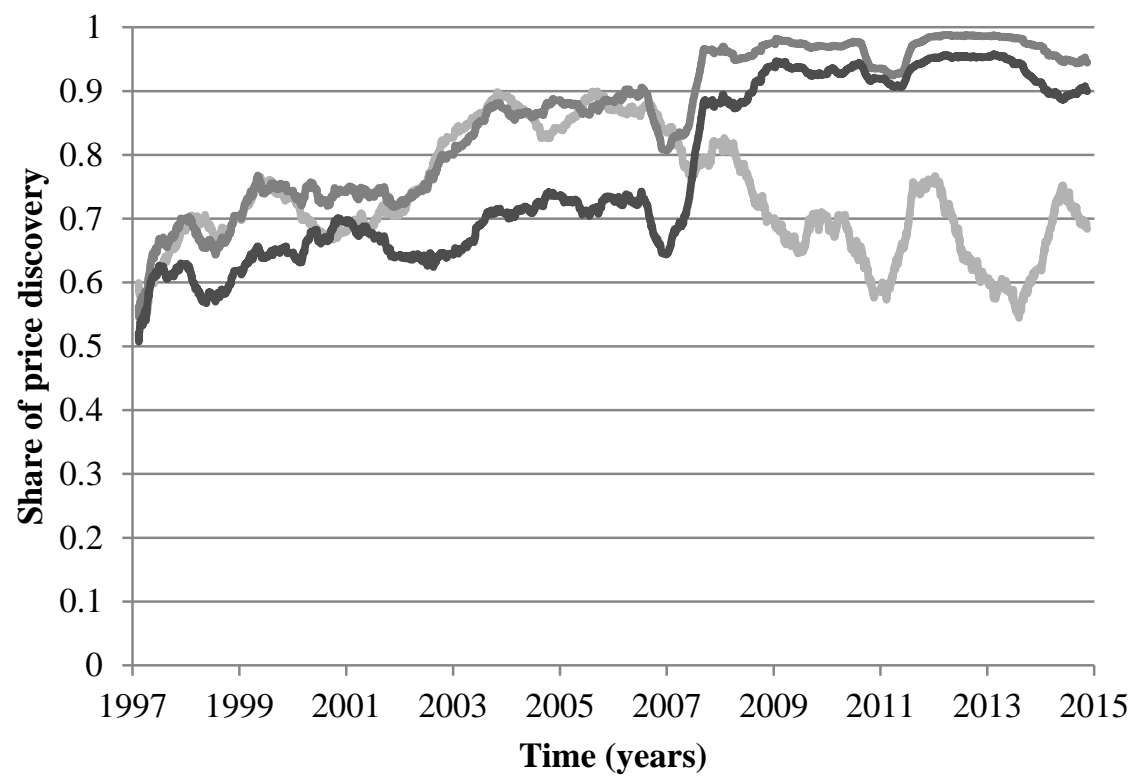

$\longrightarrow$ ILS IS CS

\section{Figure 1}

Futures market price discovery shares through time

Note: This figure plots the futures market (COMEX) price discovery shares through time. Each line is a 180-day moving average of the daily price discovery estimates. The daily estimates of Information Shares (IS), Component Shares $(C S)$, and Information Leadership Shares (ILS) are calculated using intraday data with a sampling frequency of one second. 


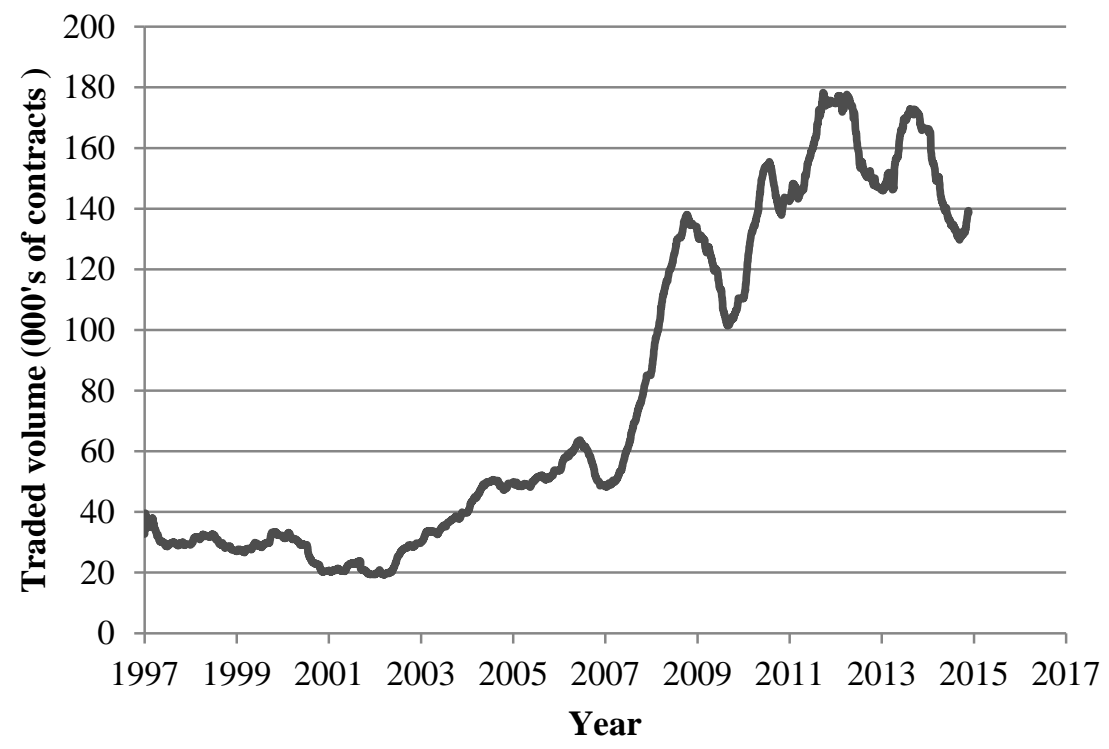

_Average Daily Volume

Figure 2

Futures market volume through time

Note: This figure plots the traded volume of gold futures contracts (the most active contract at every point in time, as specified in Table 1) through time. The line is a 180day moving average of daily traded volume. 


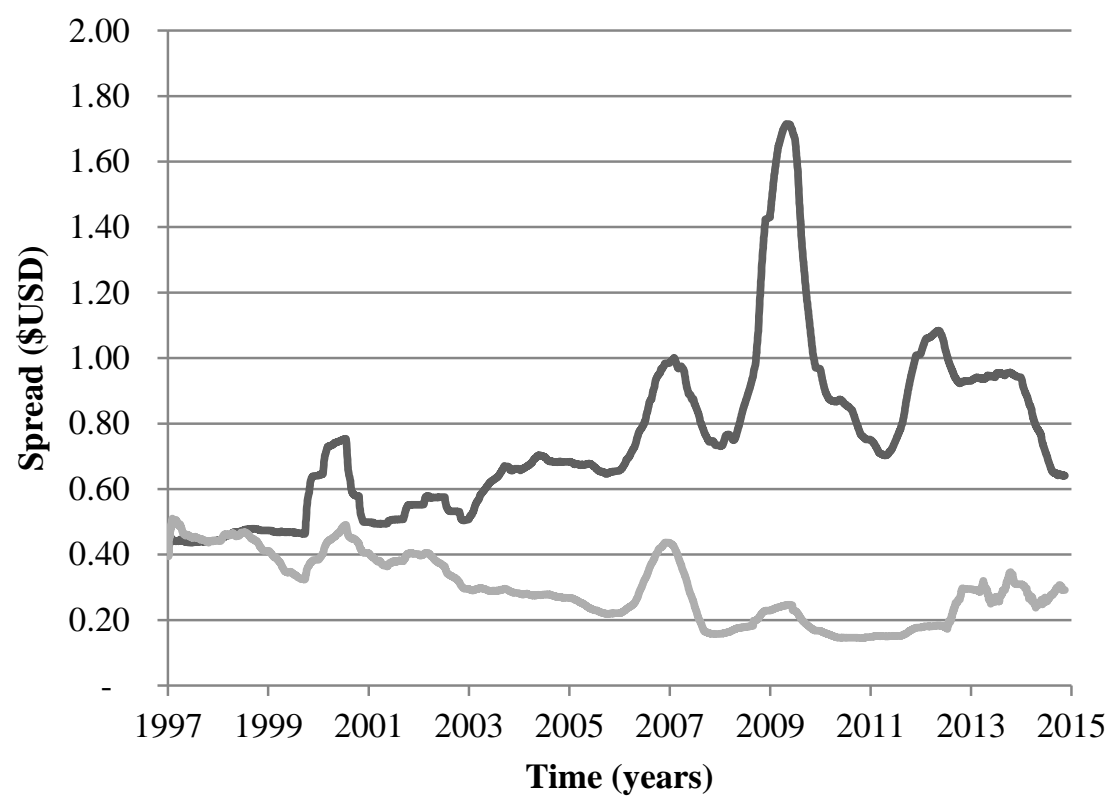

$\longrightarrow$ Spot $\longrightarrow$ Futures

Figure 3

Bid-ask spreads through time

Note: This figure plots the 180-day moving average bid-ask spread of the London OTC gold spot quotes and the New York COMEX gold futures quotes. Each quote is for one fine troy ounce and is measured in US Dollars. 
1998

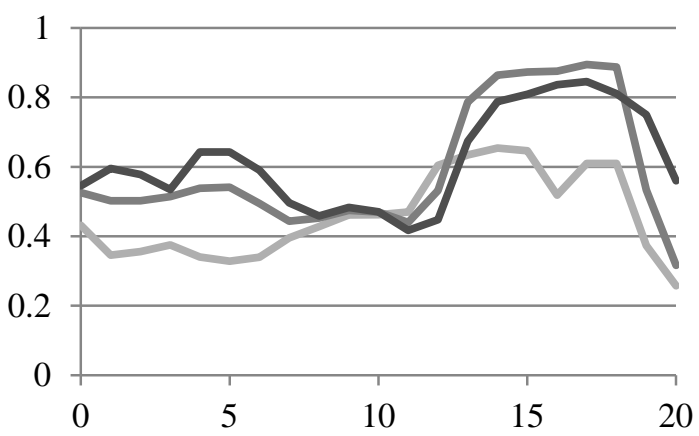

2007

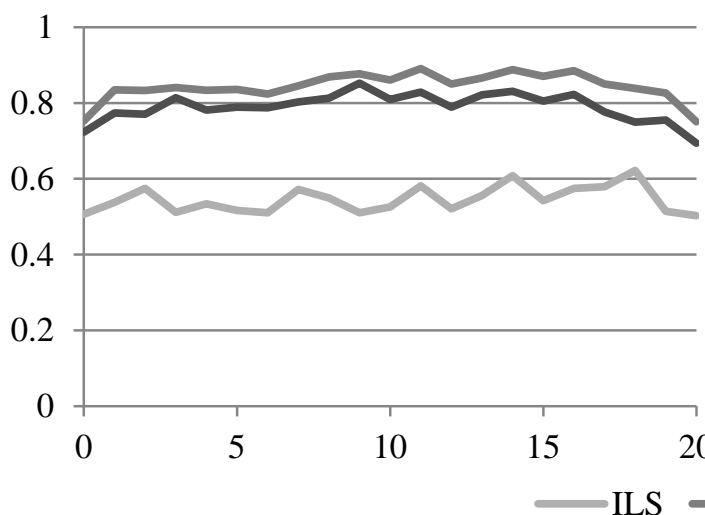

2005

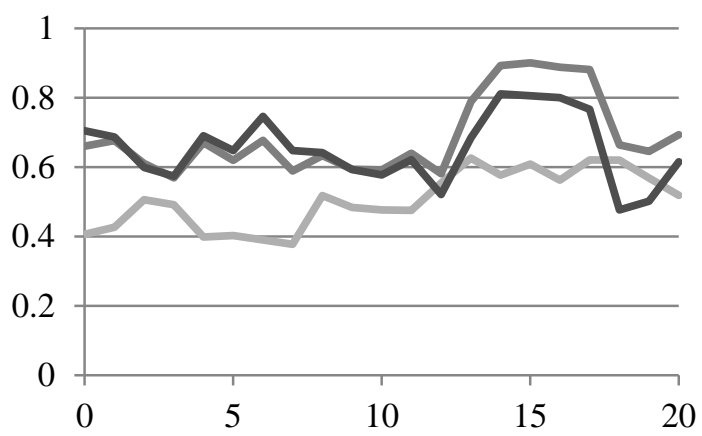

2013

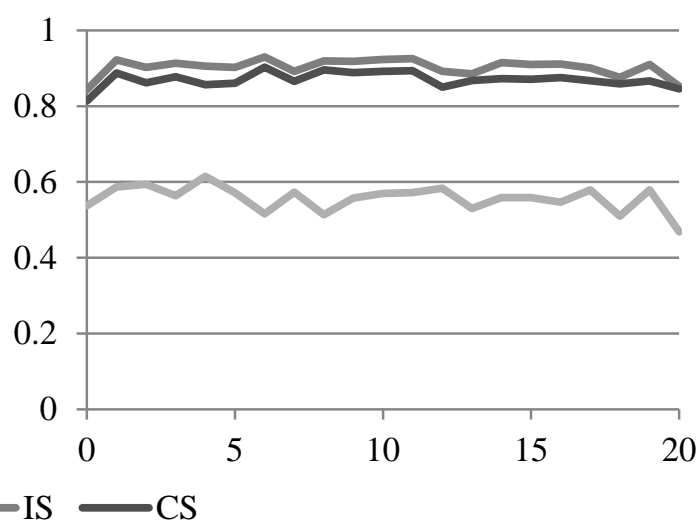

Figure 4

Intraday patterns in futures market gold price discovery shares

Note: This figure plots the futures market (COMEX) gold price discovery share intraday averages for four indicative years. Each line represents an average of the hourly price discovery estimates (Information Shares $(I S)$, Component Shares (CS), and Information Leadership Shares (ILS)), which are estimated using intraday data sampled at a one-second frequency. The title of each graph is the year during which the intraday averages are estimated and the horizontal axis measures intraday time in GMT. 
TABLE I

Most liquid gold futures contracts

\begin{tabular}{ll}
\hline Month of year & Expiry month \\
\hline January $^{\#}$ & February \\
February & April \\
March $^{\#}$ & April \\
April & June \\
May & June \\
June & August \\
July & August \\
August & December \\
September & December \\
October & December \\
November & December \\
December & February \\
\hline
\end{tabular}

Note: This table illustrates the most actively traded gold futures contracts on COMEX in each month of the year. Month of year is the calendar month of any respective trading day. Expiry month indicates the most actively traded futures contract expiry month for each calendar month. " Volume shifts to next active contract on the last two business days of this month. 
TABLE II

Global gold turnover during 2011

\begin{tabular}{lrr}
\hline & '000 Ounces & Share of total (\%) \\
\hline United Kingdom & $43,775,704$ & $86.75 \%$ \\
United States & $4,991,604$ & $9.89 \%$ \\
China & 697,002 & $1.38 \%$ \\
India & 494,547 & $0.98 \%$ \\
Japan & 488,502 & $0.97 \%$ \\
Dubai & 12,507 & $0.02 \%$ \\
Total Volume & $50,459,866$ & \\
\hline Note: This table reports the estimated trading volume and proportion of \\
volume traded in each of the six major gold trading countries for all \\
gold-related instruments, including spot and derivatives. UK data are \\
from Murray (2011), all other data are from GFMS Ltd. (2012). This \\
table is originally compiled by Lucey et al. (2013).
\end{tabular}


TABLE III

Futures market share of gold price discovery by year

\begin{tabular}{|c|c|c|c|}
\hline Year & $I S$ & $C S$ & $I L S$ \\
\hline 1997 & $0.6704 * * *$ & $0.6079 * * *$ & $0.6584 * * *$ \\
\hline 1998 & $0.6916 * * *$ & $0.6020 * * *$ & $0.7013 * * *$ \\
\hline 1999 & $0.7495^{* * *}$ & $0.6490 * * *$ & $0.7434 * * *$ \\
\hline 2000 & $0.7339 * * *$ & $0.6841 * * *$ & $0.6705 * * *$ \\
\hline 2001 & $0.7241 * * *$ & $0.6461 * * *$ & $0.7082 * * *$ \\
\hline 2002 & $0.7913 * * *$ & $0.6444 * * *$ & $0.8104 * * *$ \\
\hline 2003 & $0.8727 * * *$ & $0.7093 * * *$ & $0.8867 * * *$ \\
\hline 2004 & $0.8724 * * *$ & $0.7288 * * *$ & $0.8397 * * *$ \\
\hline 2005 & $0.8859 * * *$ & $0.7288 * * *$ & $0.8731 * * *$ \\
\hline 2006 & $0.8239 * * *$ & $0.6543 * * *$ & $0.8449 * * *$ \\
\hline 2007 & $0.9618 * * *$ & $0.8749 * * *$ & $0.8186^{* * *}$ \\
\hline 2008 & $0.9725 * * *$ & $0.9238 * * *$ & $0.7038 * * *$ \\
\hline 2009 & $0.9694 * * *$ & $0.9287 * * *$ & $0.6893 * * *$ \\
\hline 2010 & $0.9444 * * *$ & $0.9208 * * *$ & $0.6042 * * *$ \\
\hline 2011 & $0.9777 * * *$ & $0.9441 * * *$ & $0.7483 * * *$ \\
\hline 2012 & $0.9871 * * *$ & $0.9552 * * *$ & $0.6139 * * *$ \\
\hline 2013 & $0.9740 * * *$ & $0.9241 * * *$ & $0.6118 * * *$ \\
\hline 2014 & $0.9400 * * *$ & $0.8915^{* * *}$ & $0.7094 * * *$ \\
\hline
\end{tabular}

Note: This table reports annual averages of daily gold price discovery shares (estimated form one-second intraday observations) for the New York (COMEX) futures market. The futures market price discovery shares, which are estimated relative to the London spot market, are: Information Shares (IS), Component Shares $(C S)$, and Information Leadership Shares $(I L S)$. ${ }^{* * *}$ denotes an estimate is significantly different from 0.50 at the $1 \%$ level. 
TABLE IV

Regressions of hourly futures market gold price discovery shares

\begin{tabular}{|c|c|c|c|c|c|c|c|c|c|}
\hline \multirow{3}{*}{ INTERCEPT } & \multicolumn{3}{|c|}{$C S$} & \multicolumn{3}{|c|}{$I S$} & \multicolumn{3}{|c|}{$I L S$} \\
\hline & Model 1 & Model 2 & Model 3 & Model 1 & Model 2 & Model 3 & Model 1 & Model 2 & Model 3 \\
\hline & $\begin{array}{c}0.70 * * * \\
(165.24)\end{array}$ & $\begin{array}{c}0.68 * * * \\
(120.95)\end{array}$ & $\begin{array}{c}0.69 * * * \\
(99.71)\end{array}$ & $\begin{array}{l}0.66 * * * \\
(154.09)\end{array}$ & $\begin{array}{c}0.63 * * * \\
(112.47)\end{array}$ & $\begin{array}{c}0.61 * * * \\
(86.71)\end{array}$ & $\begin{array}{l}0.45 * * * \\
(76.26)\end{array}$ & $\begin{array}{l}0.43 * * * \\
(61.33)\end{array}$ & $\begin{array}{l}0.40 * * * \\
(46.89)\end{array}$ \\
\hline POST & $\begin{array}{c}0.16^{* * * *} \\
(71.96)\end{array}$ & $\begin{array}{c}0.17 * * * \\
(29.86)\end{array}$ & $\begin{array}{c}0.15^{* * *} \\
(17.67)\end{array}$ & $\begin{array}{c}0.17 * * * \\
(76.88)\end{array}$ & $\begin{array}{c}0.20 * * * \\
(35.89)\end{array}$ & $\begin{array}{c}0.22 * * * \\
(26.57)\end{array}$ & $\begin{array}{c}0.00 \\
(0.86)\end{array}$ & $\begin{array}{l}0.02 * * \\
(2.38)\end{array}$ & $\begin{array}{c}0.07 * * * \\
(5.57)\end{array}$ \\
\hline ASIA & $\begin{array}{c}0.02 * * * \\
(5.33)\end{array}$ & $\begin{array}{c}0.02 * * * \\
(3.77)\end{array}$ & $\begin{array}{l}0.01 * * \\
(2.37)\end{array}$ & $\begin{array}{l}0.01 * * \\
(2.41)\end{array}$ & $\begin{array}{c}-0.01 * * \\
(-2.40)\end{array}$ & $\begin{array}{c}-0.02 * * * \\
(-3.45)\end{array}$ & $\begin{array}{c}-0.01 \\
(-1.33)\end{array}$ & $\begin{array}{c}-0.04 * * * \\
(-7.66)\end{array}$ & $\begin{array}{c}-0.05 * * * \\
(-7.70)\end{array}$ \\
\hline ASIA*POST & & $\begin{array}{l}-0.01 * \\
(-1.94)\end{array}$ & $\begin{array}{c}0.00 \\
(0.38)\end{array}$ & & $\begin{array}{c}0.03 * * * \\
(5.41)\end{array}$ & $\begin{array}{c}0.04 * * * \\
(7.21)\end{array}$ & & $\begin{array}{c}0.07 * * * \\
(9.09)\end{array}$ & $\begin{array}{c}0.08 * * * \\
(9.05)\end{array}$ \\
\hline USA & $\begin{array}{c}0.04 * * * \\
(12.35)\end{array}$ & $\begin{array}{c}0.09 * * * \\
(17.11)\end{array}$ & $\begin{array}{c}0.08 * * * \\
(14.18)\end{array}$ & $\begin{array}{c}0.06 * * * \\
(18.65)\end{array}$ & $\begin{array}{c}0.13 * * * \\
(25.13)\end{array}$ & $\begin{array}{c}0.12 * * * \\
(21.07)\end{array}$ & $\begin{array}{c}0.03 * * * \\
(5.97)\end{array}$ & $\begin{array}{c}0.06^{* * *} \\
(9.25)\end{array}$ & $\begin{array}{c}0.06 * * * \\
(7.76)\end{array}$ \\
\hline USA*POST & & $\begin{array}{c}-0.09 * * * \\
(-14.69)\end{array}$ & $\begin{array}{c}-0.06 * * * \\
(-9.47)\end{array}$ & & $\begin{array}{c}-0.12 * * * \\
(-20.80)\end{array}$ & $\begin{array}{c}-0.09 * * * \\
(-13.77)\end{array}$ & & $\begin{array}{c}-0.05 * * * \\
(-5.65)\end{array}$ & $\begin{array}{c}-0.04 * * * \\
(-3.56)\end{array}$ \\
\hline UK & $\begin{array}{c}0.02 * * * \\
(6.14)\end{array}$ & $\begin{array}{c}-0.01 * * * \\
(-3.31)\end{array}$ & $\begin{array}{c}-0.02 * * * \\
(-4.35)\end{array}$ & $\begin{array}{c}0.04 * * * \\
(16.35)\end{array}$ & $\begin{array}{c}0.03 * * * \\
(8.31)\end{array}$ & $\begin{array}{c}0.03 * * * \\
(6.67)\end{array}$ & $\begin{array}{c}0.04 * * * \\
(11.12)\end{array}$ & $\begin{array}{c}0.06 * * * \\
(12.62)\end{array}$ & $\begin{array}{c}0.06 * * * \\
(11.89)\end{array}$ \\
\hline UK*POST & & $\begin{array}{c}0.06^{* * *} \\
(13.17)\end{array}$ & $\begin{array}{c}0.07 * * * \\
(13.94)\end{array}$ & & $\begin{array}{c}0.02 * * * \\
(3.76)\end{array}$ & $\begin{array}{c}0.03 * * * \\
(5.25)\end{array}$ & & $\begin{array}{c}-0.04 * * * \\
(-6.51)\end{array}$ & $\begin{array}{c}-0.04 * * * \\
(-5.68)\end{array}$ \\
\hline FTRSPREAD & $\begin{array}{c}-0.35 * * * \\
(-39.13)\end{array}$ & $\begin{array}{c}-0.28 * * * \\
(-26.71)\end{array}$ & $\begin{array}{c}-0.28 * * * \\
(-25.19)\end{array}$ & $\begin{array}{c}-0.41 * * * \\
(-41.03)\end{array}$ & $\begin{array}{c}-0.30 * * * \\
(-27.07)\end{array}$ & $\begin{array}{c}-0.30 * * * \\
(-25.91)\end{array}$ & $\begin{array}{c}-0.12 * * * \\
(-10.46)\end{array}$ & $\begin{array}{c}-0.04 * * * \\
(-3.28)\end{array}$ & $\begin{array}{c}-0.04 * * * \\
(-3.52)\end{array}$ \\
\hline FTRSPREAD*POST & & & $\begin{array}{c}-0.03 \\
(-0.92)\end{array}$ & & & $\begin{array}{l}0.06^{*} \\
(1.71)\end{array}$ & & & $\begin{array}{l}0.10 * * \\
(2.23)\end{array}$ \\
\hline SPOTSPREAD & $\begin{array}{c}0.02 * * * \\
(6.95)\end{array}$ & $\begin{array}{c}0.02 * * * \\
(5.84)\end{array}$ & $\begin{array}{l}0.01 * * \\
(2.03)\end{array}$ & $\begin{array}{c}0.06^{* * * *} \\
(18.36)\end{array}$ & $\begin{array}{c}0.05 * * * \\
(15.84)\end{array}$ & $\begin{array}{c}0.10 * * * \\
(13.86)\end{array}$ & $\begin{array}{c}0.06 * * * \\
(12.48)\end{array}$ & $\begin{array}{c}0.05 * * * \\
(10.78)\end{array}$ & $\begin{array}{c}0.11 * * * \\
(13.18)\end{array}$ \\
\hline SPOTSPREAD*POST & & & $\begin{array}{c}0.01 \\
(1.26)\end{array}$ & & & $\begin{array}{c}-0.07 * * * \\
(-8.48)\end{array}$ & & & $\begin{array}{c}-0.10 * * * \\
(-8.71)\end{array}$ \\
\hline AMFIX & $\begin{array}{c}0.02 * * * \\
(4.29)\end{array}$ & $\begin{array}{c}0.02 * * * \\
(3.73)\end{array}$ & $\begin{array}{c}0.01 \\
(1.23)\end{array}$ & $\begin{array}{l}0.01 * * \\
(2.40)\end{array}$ & $\begin{array}{c}0.01 \\
(1.50)\end{array}$ & $\begin{array}{l}-0.01 \\
(-1.25)\end{array}$ & $\begin{array}{c}-0.01 \\
(-1.19)\end{array}$ & $\begin{array}{c}-0.01 \\
(-1.59)\end{array}$ & $\begin{array}{c}-0.03 * * * \\
(-2.86)\end{array}$ \\
\hline AMFIX*POST & & & $\begin{array}{c}0.02 \\
(1.60)\end{array}$ & & & $\begin{array}{c}0.04 * * * \\
(4.05)\end{array}$ & & & $\begin{array}{l}0.04 * * \\
(2.47)\end{array}$ \\
\hline PMFIX & $\begin{array}{c}0.02 * * * \\
(4.46)\end{array}$ & $\begin{array}{c}0.02 * * * \\
(4.28)\end{array}$ & $\begin{array}{c}0.05^{* * *} \\
(7.67)\end{array}$ & $\begin{array}{c}0.02 * * * \\
(6.06)\end{array}$ & $\begin{array}{c}0.02 * * * \\
(5.86)\end{array}$ & $\begin{array}{c}0.05^{* * *} * \\
(9.07)\end{array}$ & $\begin{array}{c}-0.01 \\
(-0.94)\end{array}$ & $\begin{array}{c}-0.01 \\
(-1.05)\end{array}$ & $\begin{array}{c}0.00 \\
(0.07)\end{array}$ \\
\hline PMFIX*POST & & & $\begin{array}{c}-0.07 * * * \\
(-8.43)\end{array}$ & & & $\begin{array}{c}-0.07 * * * \\
(-9.21)\end{array}$ & & & $\begin{array}{c}-0.02 \\
(-1.23)\end{array}$ \\
\hline UKRATE & $\begin{array}{c}0.00 \\
(-0.22)\end{array}$ & $\begin{array}{l}-0.01 \\
(-0.32)\end{array}$ & $\begin{array}{c}-0.02 \\
(-0.48)\end{array}$ & $\begin{array}{c}-0.01 \\
(-0.33)\end{array}$ & $\begin{array}{c}-0.01 \\
(-0.43)\end{array}$ & $\begin{array}{c}-0.04 \\
(-0.99)\end{array}$ & $\begin{array}{c}-0.01 \\
(-0.38)\end{array}$ & $\begin{array}{c}-0.01 \\
(-0.38)\end{array}$ & $\begin{array}{c}-0.04 \\
(-0.91)\end{array}$ \\
\hline UKRATE*POST & & & $\begin{array}{c}0.02 \\
(0.56)\end{array}$ & & & $\begin{array}{c}0.06 \\
(1.33)\end{array}$ & & & $\begin{array}{c}0.05 \\
(0.83)\end{array}$ \\
\hline USRATE & $\begin{array}{c}-0.04 \\
(-1.38)\end{array}$ & $\begin{array}{c}-0.05 \\
(-1.59)\end{array}$ & $\begin{array}{c}0.00 \\
(-0.07)\end{array}$ & $\begin{array}{l}-0.05^{*} \\
(-1.86)\end{array}$ & $\begin{array}{c}-0.06^{* *} \\
(-2.16)\end{array}$ & $\begin{array}{c}-0.02 \\
(-0.61)\end{array}$ & $\begin{array}{c}-0.02 \\
(-0.60)\end{array}$ & $\begin{array}{c}-0.03 \\
(-0.68)\end{array}$ & $\begin{array}{c}0.00 \\
(-0.08)\end{array}$ \\
\hline USRATE*POST & & & $\begin{array}{l}-0.09 \\
(-1.56)\end{array}$ & & & $\begin{array}{l}-0.07 \\
(-1.32)\end{array}$ & & & $\begin{array}{c}-0.04 \\
(-0.58)\end{array}$ \\
\hline UKEMPLOY & $\begin{array}{c}-0.03 \\
(-1.52)\end{array}$ & $\begin{array}{c}-0.03 \\
(-1.63)\end{array}$ & $\begin{array}{c}-0.07 * * \\
(-2.13)\end{array}$ & $\begin{array}{c}-0.05 * * \\
(-2.20)\end{array}$ & $\begin{array}{c}-0.05 * * \\
(-2.31)\end{array}$ & $\begin{array}{c}-0.10 * * * \\
(-2.67)\end{array}$ & $\begin{array}{c}-0.01 \\
(-0.37)\end{array}$ & $\begin{array}{c}-0.01 \\
(-0.40)\end{array}$ & $\begin{array}{c}-0.02 \\
(-0.43)\end{array}$ \\
\hline UKEMPLOY*POST & & & $\begin{array}{c}0.09 * * \\
(2.28)\end{array}$ & & & $\begin{array}{c}0.11 * * * \\
(2.69)\end{array}$ & & & $\begin{array}{c}0.01 \\
(0.21)\end{array}$ \\
\hline
\end{tabular}


TABLE IV CONT.

Regressions of hourly futures market gold price discovery shares

\begin{tabular}{|c|c|c|c|c|c|c|c|c|c|}
\hline & \multicolumn{3}{|c|}{$C S$} & \multicolumn{3}{|c|}{$I S$} & \multicolumn{3}{|c|}{$I L S$} \\
\hline & Model 1 & Model 2 & Model 3 & Model 1 & Model 2 & Model 3 & Model 1 & Model 2 & Model 3 \\
\hline USEMPLOY & $\begin{array}{c}-0.09 * * * \\
(-3.61)\end{array}$ & $\begin{array}{c}-0.09 * * * \\
(-3.45)\end{array}$ & $\begin{array}{c}-0.13 * * * \\
(-3.13)\end{array}$ & $\begin{array}{c}-0.06 * * * \\
(-2.65)\end{array}$ & $\begin{array}{c}-0.05 * * \\
(-2.28)\end{array}$ & $\begin{array}{l}-0.07 * \\
(-1.94)\end{array}$ & $\begin{array}{c}0.02 \\
(0.53)\end{array}$ & $\begin{array}{c}0.02 \\
(0.70)\end{array}$ & $\begin{array}{c}0.01 \\
(0.18)\end{array}$ \\
\hline USEMPLOY*POST & & & $\begin{array}{l}0.08 * \\
(1.73)\end{array}$ & & & $\begin{array}{c}0.04 \\
(0.89)\end{array}$ & & & $\begin{array}{c}0.03 \\
(0.49)\end{array}$ \\
\hline UKGDP & $\begin{array}{c}0.00 \\
(0.05)\end{array}$ & $\begin{array}{c}0.00 \\
(-0.10)\end{array}$ & $\begin{array}{c}-0.01 \\
(-0.17)\end{array}$ & $\begin{array}{c}0.00 \\
(-0.19)\end{array}$ & $\begin{array}{c}-0.01 \\
(-0.31)\end{array}$ & $\begin{array}{c}-0.03 \\
(-0.86)\end{array}$ & $\begin{array}{c}0.00 \\
(-0.03)\end{array}$ & $\begin{array}{c}0.00 \\
(-0.03)\end{array}$ & $\begin{array}{c}-0.04 \\
(-1.08)\end{array}$ \\
\hline UKGDP*POST & & & $\begin{array}{c}0.01 \\
(0.21)\end{array}$ & & & $\begin{array}{c}0.05 \\
(1.25)\end{array}$ & & & $\begin{array}{c}0.08 \\
(1.35)\end{array}$ \\
\hline USGDP & $\begin{array}{c}-0.12 * * * \\
(-5.06)\end{array}$ & $\begin{array}{c}-0.11 * * * \\
(-5.09)\end{array}$ & $\begin{array}{c}-0.21 * * * \\
(-5.96)\end{array}$ & $\begin{array}{c}-0.05 * * * \\
(-2.61)\end{array}$ & $\begin{array}{c}-0.05^{* *} \\
(-2.27)\end{array}$ & $\begin{array}{c}-0.09 * * \\
(-2.45)\end{array}$ & $\begin{array}{c}0.08 * * * \\
(2.73)\end{array}$ & $\begin{array}{c}0.09 * * * \\
(2.95)\end{array}$ & $\begin{array}{c}0.16^{* * * *} \\
(4.63)\end{array}$ \\
\hline USGDP*POST & & & $\begin{array}{c}0.20 * * * \\
(5.06)\end{array}$ & & & $\begin{array}{c}0.08 * * \\
(2.13)\end{array}$ & & & $\begin{array}{c}-0.16^{* * * *} \\
(-2.82)\end{array}$ \\
\hline UKPPI & $\begin{array}{c}-0.02 \\
(-1.13)\end{array}$ & $\begin{array}{c}-0.02 \\
(-1.19)\end{array}$ & $\begin{array}{c}-0.03 \\
(-0.99)\end{array}$ & $\begin{array}{c}-0.02 \\
(-0.80)\end{array}$ & $\begin{array}{c}-0.02 \\
(-0.93)\end{array}$ & $\begin{array}{c}-0.02 \\
(-0.61)\end{array}$ & $\begin{array}{c}0.01 \\
(0.23)\end{array}$ & $\begin{array}{c}0.00 \\
(0.15)\end{array}$ & $\begin{array}{c}0.00 \\
(-0.03)\end{array}$ \\
\hline UKPPI*POST & & & $\begin{array}{c}0.03 \\
(0.78)\end{array}$ & & & $\begin{array}{c}0.01 \\
(0.36)\end{array}$ & & & $\begin{array}{c}0.02 \\
(0.36)\end{array}$ \\
\hline USPPI & $\begin{array}{c}-0.05^{* *} \\
(-2.55)\end{array}$ & $\begin{array}{c}-0.05^{* *} \\
(-2.48)\end{array}$ & $\begin{array}{c}-0.09^{* *} \\
(-2.53)\end{array}$ & $\begin{array}{c}-0.02 \\
(-1.09)\end{array}$ & $\begin{array}{c}-0.02 \\
(-0.81)\end{array}$ & $\begin{array}{c}-0.04 \\
(-1.19)\end{array}$ & $\begin{array}{l}0.06^{*} \\
(1.81)\end{array}$ & $\begin{array}{c}0.06^{* *} \\
(1.99)\end{array}$ & $\begin{array}{c}0.05 \\
(1.14)\end{array}$ \\
\hline USPPI*POST & & & $\begin{array}{l}0.08^{*} \\
(1.88)\end{array}$ & & & $\begin{array}{c}0.05 \\
(1.36)\end{array}$ & & & $\begin{array}{c}0.03 \\
(0.43)\end{array}$ \\
\hline UKCPI & $\begin{array}{c}0.07 * * * \\
(3.88)\end{array}$ & $\begin{array}{c}0.05^{* * * *} \\
(3.10)\end{array}$ & $\begin{array}{c}0.13 * * * \\
(2.78)\end{array}$ & $\begin{array}{c}0.05 * * * \\
(3.01)\end{array}$ & $\begin{array}{c}0.04 * * \\
(2.39)\end{array}$ & $\begin{array}{c}0.12 * * \\
(2.38)\end{array}$ & $\begin{array}{c}-0.03 \\
(-0.69)\end{array}$ & $\begin{array}{c}-0.03 \\
(-0.68)\end{array}$ & $\begin{array}{c}0.07 \\
(0.96)\end{array}$ \\
\hline UKCPI*POST & & & $\begin{array}{c}-0.11 * * \\
(-2.25)\end{array}$ & & & $\begin{array}{c}-0.12 * * \\
(-2.18)\end{array}$ & & & $\begin{array}{c}-0.13(- \\
1.60)\end{array}$ \\
\hline USCPI & $\begin{array}{c}-0.05^{* *} \\
(-2.40)\end{array}$ & $\begin{array}{c}-0.05^{* *} \\
(-2.42)\end{array}$ & $\begin{array}{c}-0.12 * * * \\
(-3.25)\end{array}$ & $\begin{array}{c}-0.03 \\
(-1.30)\end{array}$ & $\begin{array}{c}-0.02 \\
(-1.12)\end{array}$ & $\begin{array}{l}-0.06^{*} \\
(-1.75)\end{array}$ & $\begin{array}{c}0.02 \\
(0.78)\end{array}$ & $\begin{array}{c}0.03 \\
(0.93)\end{array}$ & $\begin{array}{l}0.06^{*} \\
(1.66)\end{array}$ \\
\hline USCPI*POST & & & $\begin{array}{c}0.14 * * * \\
(3.59)\end{array}$ & & & $\begin{array}{c}0.08 * * \\
(2.18)\end{array}$ & & & $\begin{array}{c}-0.08 \\
(-1.28)\end{array}$ \\
\hline
\end{tabular}

Note: This table reports regression results in which the dependent variables are hourly gold futures price discovery shares (Component Share, CS; Information Share, IS; Information Leadership Share, ILS). POST is a dummy variable that takes the value of one after COMEX introduces the GLOBEX platform. ASIA, USA, and UK are dummy variables equal to one when the Hong Kong Stock Exchange, New York Stock Exchange and London Stock Exchange are trading, respectively. FTRSPREAD and SPOTSPREAD are the average spreads for each hour on COMEX and LOTC, respectively. AMFIX and PMFIX are dummy variables equal to one in the hour that the London gold fixing occurs. UKRATE and USRATE are dummy variables equal to one in the hour that the UK and US central banks announce a new target interest rate, respectively. UKEMPLOY and USEMPLOY are dummy variables equal to one in the hour that the UK and US governments announce employment figures, respectively. UKGDP and USGDP are dummy variables equal to one in the hour that the UK and US governments announce GDP figures, respectively. UKPPI and USPPI are dummy variables equal to one in the hour that the UK and US governments announce PPI figures, respectively. UKCPI and USCPI are dummy variables equal to one in the hour that the UK and US governments announce CPI figures, respectively. Newey-West $t$-statistics are reported in parenthesis. ${ }^{* * *}, * *$ and $*$ denote statistical significance at $1 \%, 5 \%$ and $10 \%$ level, respectively. 
TABLE V

Regressions of hourly futures market gold price discovery shares with 460 lags

\begin{tabular}{|c|c|c|c|c|c|c|c|c|c|}
\hline & \multicolumn{3}{|c|}{$C S$} & \multicolumn{3}{|c|}{$I S$} & \multicolumn{3}{|c|}{ ILS } \\
\hline & Model 1 & Model 2 & Model 3 & Model 1 & Model 2 & Model 3 & Model 1 & Model 2 & Model 3 \\
\hline INTERCEPT & $\begin{array}{l}0.62 * * * \\
(120.59)\end{array}$ & $\begin{array}{l}0.62 * * * \\
(95.09)\end{array}$ & $\begin{array}{l}0.65^{* * * *} \\
(81.46)\end{array}$ & $\begin{array}{l}0.59 * * * \\
(122.72)\end{array}$ & $\begin{array}{l}0.57 * * * \\
(96.03)\end{array}$ & $\begin{array}{l}0.56 * * * \\
(74.52)\end{array}$ & $\begin{array}{l}0.44 * * * \\
(73.67)\end{array}$ & $\begin{array}{l}0.43 * * * \\
(58.19)\end{array}$ & $\begin{array}{l}0.40^{* * *} \\
(44.12)\end{array}$ \\
\hline POST & $\begin{array}{l}0.13 * * * \\
(46.10)\end{array}$ & $\begin{array}{l}0.12 * * * \\
(16.74)\end{array}$ & $\begin{array}{l}0.08 * * * \\
(6.95)\end{array}$ & $\begin{array}{l}0.10^{* * * *} \\
(38.02)\end{array}$ & $\begin{array}{l}0.10 * * * \\
(15.05)\end{array}$ & $\begin{array}{l}0.13 * * * \\
(12.72)\end{array}$ & $\begin{array}{l}-0.05 * * * \\
(-14.06)\end{array}$ & $\begin{array}{l}-0.03 * * * \\
(-3.77)\end{array}$ & $\begin{array}{l}0.00 \\
(0.31)\end{array}$ \\
\hline ASIA & $\begin{array}{l}0.05 * * * \\
(13.11)\end{array}$ & $\begin{array}{l}0.06^{* * * *} \\
(10.51)\end{array}$ & $\begin{array}{l}0.05^{* * * *} \\
(8.54)\end{array}$ & $\begin{array}{l}0.02 * * * \\
(6.56)\end{array}$ & $\begin{array}{l}-0.01 \\
(-0.98)\end{array}$ & $\begin{array}{l}-0.01 * \\
(-1.95)\end{array}$ & $\begin{array}{l}-0.03 * * * \\
(-6.87)\end{array}$ & $\begin{array}{l}-0.06 * * * \\
(-9.86)\end{array}$ & $\begin{array}{l}-0.06 * * * \\
(-8.71)\end{array}$ \\
\hline ASIA*POST & & $\begin{array}{l}-0.02 * * * \\
(-2.88)\end{array}$ & $\begin{array}{l}0.00 \\
(-0.36)\end{array}$ & & $\begin{array}{l}0.05 * * * \\
(7.89)\end{array}$ & $\begin{array}{l}0.06 * * * \\
(8.97)\end{array}$ & & $\begin{array}{l}0.06 * * * \\
(7.09)\end{array}$ & $\begin{array}{l}0.05^{* * *} \\
(5.63)\end{array}$ \\
\hline USA & $\begin{array}{l}0.03 * * * \\
(7.17)\end{array}$ & $\begin{array}{l}0.04 * * * \\
(6.78)\end{array}$ & $\begin{array}{l}0.03 * * * \\
(4.92)\end{array}$ & $\begin{array}{l}0.06 * * * \\
(15.75)\end{array}$ & $\begin{array}{l}0.11 * * * \\
(19.90)\end{array}$ & $\begin{array}{l}0.10 * * * \\
(17.25)\end{array}$ & $\begin{array}{l}0.03 * * * \\
(4.99)\end{array}$ & $\begin{array}{l}0.06 * * * \\
(8.08)\end{array}$ & $\begin{array}{l}0.06 * * * \\
(7.92)\end{array}$ \\
\hline USA*POST & & $\begin{array}{l}-0.02 * * * \\
(-3.07)\end{array}$ & $\begin{array}{l}0.00 \\
(-0.16)\end{array}$ & & $\begin{array}{l}-0.08 * * * \\
(-11.97)\end{array}$ & $\begin{array}{l}-0.06 * * * \\
(-8.07)\end{array}$ & & $\begin{array}{l}-0.05^{* * * *} \\
(-5.54)\end{array}$ & $\begin{array}{l}-0.05 * * * \\
(-5.41)\end{array}$ \\
\hline UK & $\begin{array}{l}0.03 * * * \\
(10.54)\end{array}$ & $\begin{array}{l}0.01 * \\
(1.85)\end{array}$ & $\begin{array}{l}0.00 \\
(0.64)\end{array}$ & $\begin{array}{l}0.04 * * * \\
(13.74)\end{array}$ & $\begin{array}{l}0.02 * * * \\
(5.41)\end{array}$ & $\begin{array}{l}0.02 * * * \\
(4.60)\end{array}$ & $\begin{array}{l}0.01 * * * \\
(3.24)\end{array}$ & $\begin{array}{l}0.03 * * * \\
(5.53)\end{array}$ & $\begin{array}{l}0.03 * * * \\
(6.15)\end{array}$ \\
\hline UK*POST & & $\begin{array}{l}0.05 * * * \\
(9.25)\end{array}$ & $\begin{array}{l}0.06^{* * *} \\
(10.07)\end{array}$ & & $\begin{array}{l}0.04 * * * \\
(7.07)\end{array}$ & $\begin{array}{l}0.04 * * * \\
(6.94)\end{array}$ & & $\begin{array}{l}-0.03 * * * \\
(-5.02)\end{array}$ & $\begin{array}{l}-0.04 * * * \\
(-5.68)\end{array}$ \\
\hline FTRSPREAD & $\begin{array}{l}-0.24 * * * \\
(-24.63)\end{array}$ & $\begin{array}{l}-0.22 * * * \\
(-19.76)\end{array}$ & $\begin{array}{l}-0.22 * * * \\
(-18.36)\end{array}$ & $\begin{array}{l}-0.28 * * * \\
(-29.66)\end{array}$ & $\begin{array}{l}-0.18 * * * \\
(-17.80)\end{array}$ & $\begin{array}{l}-0.18 * * * \\
(-16.85)\end{array}$ & $\begin{array}{l}-0.03 * * * \\
(-3.15)\end{array}$ & $\begin{array}{l}0.03 * * * \\
(2.68)\end{array}$ & $\begin{array}{l}0.02 \\
(1.46)\end{array}$ \\
\hline FTRSPREAD*POST & & & $\begin{array}{l}-0.07 \\
(-1.58)\end{array}$ & & & $\begin{array}{l}0.00 \\
(0.01)\end{array}$ & & & $\begin{array}{l}0.22 * * * \\
(4.22)\end{array}$ \\
\hline SPOTSPREAD & $\begin{array}{l}-0.01 * * \\
(-2.16)\end{array}$ & $\begin{array}{l}-0.01 * \\
(-1.93)\end{array}$ & $\begin{array}{l}-0.04 * * * \\
(-5.28)\end{array}$ & $\begin{array}{l}0.04 * * * \\
(10.82)\end{array}$ & $\begin{array}{l}0.03 * * * \\
(8.96)\end{array}$ & $\begin{array}{l}0.07 * * * \\
(9.37)\end{array}$ & $\begin{array}{l}0.06^{* * * *} \\
(12.70)\end{array}$ & $\begin{array}{l}0.06^{* * * *} \\
(11.23)\end{array}$ & $\begin{array}{l}0.10 * * * \\
(10.76)\end{array}$ \\
\hline SPOTSPREAD*POST & & & $\begin{array}{l}0.05^{* * * *} \\
(5.50)\end{array}$ & & & $\begin{array}{l}-0.06 * * * * \\
(-5.97)\end{array}$ & & & $\begin{array}{l}-0.08 * * * \\
(-6.93)\end{array}$ \\
\hline AMFIX & $\begin{array}{l}0.03 * * * \\
(5.83)\end{array}$ & $\begin{array}{l}0.03 * * * \\
(5.72)\end{array}$ & $\begin{array}{l}0.02 * \\
(1.84)\end{array}$ & $\begin{array}{l}0.02 * * * \\
(3.58)\end{array}$ & $\begin{array}{l}0.02 * * * \\
(2.91)\end{array}$ & $\begin{array}{l}-0.01 \\
(-0.71)\end{array}$ & $\begin{array}{l}-0.02 * * * \\
(-2.99)\end{array}$ & $\begin{array}{l}-0.02 * * * \\
(-3.31)\end{array}$ & $\begin{array}{l}-0.03 * * * \\
(-2.82)\end{array}$ \\
\hline AMFIX*POST & & & $\begin{array}{l}0.03 * * * \\
(2.84)\end{array}$ & & & $\begin{array}{l}0.05 * * * \\
(4.30)\end{array}$ & & & $\begin{array}{l}0.01 \\
(0.79)\end{array}$ \\
\hline PMFIX & $\begin{array}{l}0.01 * * \\
(2.20)\end{array}$ & $\begin{array}{l}0.01 * * \\
(2.20)\end{array}$ & $\begin{array}{l}0.04 * * * \\
(5.08)\end{array}$ & $\begin{array}{l}0.01 \\
(1.41)\end{array}$ & $\begin{array}{l}0.01 \\
(1.48)\end{array}$ & $\begin{array}{l}0.02 * * * \\
(3.18)\end{array}$ & $\begin{array}{l}0.00 \\
(0.18)\end{array}$ & $\begin{array}{l}0.00 \\
(0.20)\end{array}$ & $\begin{array}{l}-0.02 * \\
(-1.94)\end{array}$ \\
\hline PMFIX*POST & & & $\begin{array}{l}-0.07 * * * \\
(-5.66)\end{array}$ & & & $\begin{array}{l}-0.03 * * * \\
(-3.24)\end{array}$ & & & $\begin{array}{l}0.05^{* * *} \\
(3.08)\end{array}$ \\
\hline UKRATE & $\begin{array}{l}0.00 \\
(-0.08)\end{array}$ & $\begin{array}{l}0.00 \\
(-0.12)\end{array}$ & $\begin{array}{l}-0.01 \\
(-0.36)\end{array}$ & $\begin{array}{l}0.00 \\
(0.01)\end{array}$ & $\begin{array}{l}0.00 \\
(-0.04)\end{array}$ & $\begin{array}{l}-0.04 \\
(-0.92)\end{array}$ & $\begin{array}{l}-0.01 \\
(-0.28)\end{array}$ & $\begin{array}{l}-0.01 \\
(-0.29)\end{array}$ & $\begin{array}{l}-0.03 \\
(-0.62)\end{array}$ \\
\hline UKRATE*POST & & & $\begin{array}{l}0.02 \\
(0.48)\end{array}$ & & & $\begin{array}{l}0.07 \\
(1.46)\end{array}$ & & & $\begin{array}{l}0.03 \\
(0.55)\end{array}$ \\
\hline USRATE & $\begin{array}{l}0.03 \\
(0.92)\end{array}$ & $\begin{array}{l}0.03 \\
(0.89)\end{array}$ & $\begin{array}{l}0.08^{*} \\
(1.73)\end{array}$ & $\begin{array}{l}-0.04 \\
(-1.25)\end{array}$ & $\begin{array}{l}-0.04 \\
(-1.39)\end{array}$ & $\begin{array}{l}-0.06 \\
(-1.45)\end{array}$ & $\begin{array}{l}-0.06 \\
(-1.59)\end{array}$ & $\begin{array}{l}-0.06 \\
(-1.63)\end{array}$ & $\begin{array}{l}-0.15 * * * \\
(-2.67)\end{array}$ \\
\hline USRATE*POST & & & $\begin{array}{l}-0.10 \\
(-1.61)\end{array}$ & & & $\begin{array}{l}0.04 \\
(0.66)\end{array}$ & & & $\begin{array}{l}0.17 * * \\
(2.22)\end{array}$ \\
\hline UKEMPLOY & $\begin{array}{l}-0.03 \\
(-1.13)\end{array}$ & $\begin{array}{l}-0.03 \\
(-1.17)\end{array}$ & $\begin{array}{l}-0.04 \\
(-1.08)\end{array}$ & $\begin{array}{l}-0.04 \\
(-1.60)\end{array}$ & $\begin{array}{l}-0.04^{*} \\
(-1.72)\end{array}$ & $\begin{array}{l}-0.07 * * \\
(-2.12)\end{array}$ & $\begin{array}{l}0.02 \\
(0.64)\end{array}$ & $\begin{array}{l}0.02 \\
(0.59)\end{array}$ & $\begin{array}{l}0.00 \\
(-0.04)\end{array}$ \\
\hline UKEMPLOY*POST & & & $\begin{array}{l}0.03 \\
(0.58)\end{array}$ & & & $\begin{array}{l}0.07 * \\
(1.72)\end{array}$ & & & $\begin{array}{l}0.04 \\
(0.66)\end{array}$ \\
\hline
\end{tabular}


TABLE V CONT.

Regressions of hourly futures market gold price discovery shares with 460 lags

\begin{tabular}{|c|c|c|c|c|c|c|c|c|c|}
\hline & \multicolumn{3}{|c|}{$C S$} & \multicolumn{3}{|c|}{$I S$} & \multicolumn{3}{|c|}{$I L S$} \\
\hline & Model 1 & Model 2 & Model 3 & Model 1 & Model 2 & Model 3 & Model 1 & Model 2 & Model 3 \\
\hline USEMPLOY & $\begin{array}{l}-0.08 * * * \\
(-3.03)\end{array}$ & $\begin{array}{l}-0.08 * * * \\
(-3.00)\end{array}$ & $\begin{array}{l}-0.11 * * * \\
(-2.71)\end{array}$ & $\begin{array}{l}-0.02 \\
(-0.91)\end{array}$ & $\begin{array}{l}-0.01 \\
(-0.60)\end{array}$ & $\begin{array}{l}0.00 \\
(-0.12)\end{array}$ & $\begin{array}{l}0.05^{*} \\
(1.69)\end{array}$ & $\begin{array}{l}0.06^{*} \\
(1.85)\end{array}$ & $\begin{array}{l}0.12 * * * \\
(2.85)\end{array}$ \\
\hline USEMPLOY*POST & & & $\begin{array}{l}0.06 \\
(1.04)\end{array}$ & & & $\begin{array}{l}-0.02 \\
(-0.46)\end{array}$ & & & $\begin{array}{l}-0.13^{* * *} \\
(-2.19)\end{array}$ \\
\hline UKGDP & $\begin{array}{l}0.00 \\
(-0.19)\end{array}$ & $\begin{array}{l}-0.01 \\
(-0.25)\end{array}$ & $\begin{array}{l}0.00 \\
(0.10)\end{array}$ & $\begin{array}{l}-0.01 \\
(-0.25)\end{array}$ & $\begin{array}{l}-0.01 \\
(-0.40)\end{array}$ & $\begin{array}{l}-0.02 \\
(-0.40)\end{array}$ & $\begin{array}{l}0.02 \\
(0.59)\end{array}$ & $\begin{array}{l}0.02 \\
(0.55)\end{array}$ & $\begin{array}{l}-0.02 \\
(-0.51)\end{array}$ \\
\hline UKGDP*POST & & & $\begin{array}{l}-0.02 \\
(-0.37)\end{array}$ & & & $\begin{array}{l}0.01 \\
(0.27)\end{array}$ & & & $\begin{array}{l}0.07 \\
(1.21)\end{array}$ \\
\hline USGDP & $\begin{array}{l}-0.08 * * * \\
(-3.20)\end{array}$ & $\begin{array}{l}-0.08 * * * \\
(-3.27)\end{array}$ & $\begin{array}{l}-0.18 * * * \\
(-4.43)\end{array}$ & $\begin{array}{l}-0.02 \\
(-0.81)\end{array}$ & $\begin{array}{l}-0.01 \\
(-0.60)\end{array}$ & $\begin{array}{l}-0.06 \\
(-1.64)\end{array}$ & $\begin{array}{l}0.06^{*} \\
(1.85)\end{array}$ & $\begin{array}{l}0.06 * * \\
(2.01)\end{array}$ & $\begin{array}{l}0.12 * * * \\
(2.82)\end{array}$ \\
\hline USGDP*POST & & & $\begin{array}{l}0.19 * * * \\
(4.00)\end{array}$ & & & $\begin{array}{l}0.10 * * \\
(2.18)\end{array}$ & & & $\begin{array}{l}-0.12 * * \\
(-2.00)\end{array}$ \\
\hline UKPPI & $\begin{array}{l}-0.02 \\
(-0.89)\end{array}$ & $\begin{array}{l}-0.02 \\
(-0.87)\end{array}$ & $\begin{array}{l}-0.01 \\
(-0.26)\end{array}$ & $\begin{array}{l}-0.02 \\
(-0.93)\end{array}$ & $\begin{array}{l}-0.02 \\
(-0.99)\end{array}$ & $\begin{array}{l}-0.01 \\
(-0.17)\end{array}$ & $\begin{array}{l}-0.02 \\
(-0.58)\end{array}$ & $\begin{array}{l}-0.02 \\
(-0.65)\end{array}$ & $\begin{array}{l}-0.03 \\
(-0.76)\end{array}$ \\
\hline UKPPI*POST & & & $\begin{array}{l}-0.02 \\
(-0.38)\end{array}$ & & & $\begin{array}{l}-0.03 \\
(-0.66)\end{array}$ & & & $\begin{array}{l}0.02 \\
(0.37)\end{array}$ \\
\hline USPPI & $\begin{array}{l}-0.07 * * \\
(-2.27)\end{array}$ & $\begin{array}{l}-0.07 * * \\
(-2.30)\end{array}$ & $\begin{array}{l}-0.14 * * * \\
(-3.16)\end{array}$ & $\begin{array}{l}-0.02 \\
(-0.93)\end{array}$ & $\begin{array}{l}-0.02 \\
(-0.74)\end{array}$ & $\begin{array}{l}-0.05 \\
(-1.32)\end{array}$ & $\begin{array}{l}0.04 \\
(1.11)\end{array}$ & $\begin{array}{l}0.04 \\
(1.25)\end{array}$ & $\begin{array}{l}0.08 * \\
(1.74)\end{array}$ \\
\hline USPPI*POST & & & $\begin{array}{l}0.15^{* * * *} \\
(2.65)\end{array}$ & & & $\begin{array}{l}0.06 \\
(1.24)\end{array}$ & & & $\begin{array}{l}-0.08 \\
(-1.20)\end{array}$ \\
\hline UKCPI & $\begin{array}{l}0.08^{* * * *} \\
(2.84)\end{array}$ & $\begin{array}{l}0.07 * * \\
(2.48)\end{array}$ & $\begin{array}{l}0.15^{* * *} \\
(2.47)\end{array}$ & $\begin{array}{l}0.07 * * * \\
(2.99)\end{array}$ & $\begin{array}{l}0.06^{* * *} \\
(2.40)\end{array}$ & $\begin{array}{l}0.14 * * \\
(2.51)\end{array}$ & $\begin{array}{l}-0.04 \\
(-1.05)\end{array}$ & $\begin{array}{l}-0.04 \\
(-1.06)\end{array}$ & $\begin{array}{l}-0.07 \\
(-0.94)\end{array}$ \\
\hline UKCPI*POST & & & $\begin{array}{l}-0.11 \\
(-1.58)\end{array}$ & & & $\begin{array}{l}-0.10^{*} \\
(-1.68)\end{array}$ & & & $\begin{array}{l}0.04 \\
(0.42)\end{array}$ \\
\hline USCPI & $\begin{array}{l}-0.07 * * * \\
(-2.62)\end{array}$ & $\begin{array}{l}-0.07 * * * \\
(-2.72)\end{array}$ & $\begin{array}{l}-0.11 * * * \\
(-3.06)\end{array}$ & $\begin{array}{l}-0.04 * \\
(-1.77)\end{array}$ & $\begin{array}{l}-0.04^{*} \\
(-1.69)\end{array}$ & $\begin{array}{l}-0.04 \\
(-1.27)\end{array}$ & $\begin{array}{l}0.02 \\
(0.57)\end{array}$ & $\begin{array}{l}0.02 \\
(0.70)\end{array}$ & $\begin{array}{l}0.07 \\
(1.59)\end{array}$ \\
\hline USCPI*POST & & & $\begin{array}{l}0.09^{*} \\
(1.87)\end{array}$ & & & $\begin{array}{l}0.01 \\
(0.24)\end{array}$ & & & $\begin{array}{l}-0.09 \\
(-1.54)\end{array}$ \\
\hline
\end{tabular}

Note: This table reports regression results in which the dependent variables are hourly gold futures price discovery shares (Component Share, CS; Information Share, IS; Information Leadership Share, ILS). In contrast to Table IV, the price discovery metrics here are estimated using 460 lags of one-second intervals as suggested by AIC. POST is a dummy variable that takes the value of one after COMEX introduces the GLOBEX platform. ASIA, USA, and UK are dummy variables equal to one when the Hong Kong Stock Exchange, New York Stock Exchange and London Stock Exchange are trading, respectively. FTRSPREAD and SPOTSPREAD are the average spreads for each hour on COMEX and LOTC, respectively. AMFIX and PMFIX are dummy variables equal to one in the hour that the London gold fixing occurs. UKRATE and USRATE are dummy variables equal to one in the hour that the UK and US central banks announce a new target interest rate, respectively. UKEMPLOY and USEMPLOY are dummy variables equal to one in the hour that the UK and US governments announce employment figures, respectively. UKGDP and USGDP are dummy variables equal to one in the hour that the UK and US governments announce GDP figures, respectively. UKPPI and USPPI are dummy variables equal to one in the hour that the UK and US governments announce PPI figures, respectively. UKCPI and USCPI are dummy variables equal to one in the hour that the UK and US governments announce CPI figures, respectively. Newey-West $t$-statistics are reported in parenthesis. $* * *, * *$ and $*$ denote statistical significance at $1 \%$, $5 \%$ and $10 \%$ level, respectively. 